SJ Quinney College of Law, University of Utah Utah Law Digital Commons

\title{
Tradeoffs Between Wrongful Convictions and Wrongful Acquittals: Understanding and Avoiding the Risks
}

Paul Cassell

S.J. Quinney College of Law, University of Utah, paul.cassell@law.utah.edu

Follow this and additional works at: https://dc.law.utah.edu/scholarship

Part of the Criminal Law Commons, and the Criminal Procedure Commons

\section{Recommended Citation}

Cassell, Paul, "Tradeoffs Between Wrongful Convictions and Wrongful Acquittals: Understanding and Avoiding the Risks" (2018). Utah Law Faculty Scholarship. 124.

https://dc.law.utah.edu/scholarship/124 


\title{
Tradeoffs Between Wrongful Convictions and Wrongful Acquittals: Understanding and Avoiding the Risks
}

\author{
Paul G. Cassell
}

I.INTRODUCTION 1436

II.ANALYZING THE RISKS OF WRONGFUL CONVICTIONS AND WRONGFUL ACQUITTALS 1438

A. Laudan's Unconstitutional (and Perhaps Undesirable) Proposal to Change the Burden of Proof at Trial 1439

1. The Unconstitutionality of Lowering Burdens of Proof at Trial. 1441

2. Weighing the Costs of Wrongful Convictions Against the Costs of Wrongful Acquittals

B. Distinguishing Guilty from Innocent Suspects 1450

C. Extending Parole to Avoid Wrongful Acquittals 1454

III.AVOIDING THE TRADEOFFS BETWEEN WRONGFUL CONVICTIONS

AND WRONGFUL ACQUITTALS .......................................... 1464

A. A Decision Rule for Considering Innocentric Criminal Justice Reform

B. Reforms that True Innocentrists Should Endorse......... 1467

1. Abolishing the Fourth Amendment Exclusionary Rule, and Consequently Shifting Defense Resources Away from Litigating Purely Procedural Claims

2. Replacing the Miranda Regime with the Videotaping of Custodial Interrogations 1472

3. Refocus Post-Conviction Relief on Claims of Factual Innocence 1476

\footnotetext{
* Ronald N. Boyce Presidential Professor of Criminal Law and University Distinguished Professor of Law, S.J. Quinney College of Law at the University of Utah. I appreciate the thoughtfulness of Marvin Zalman, who sent me an advance draft of his article and encouraged a response, as well as Michael Risinger for inviting me to participate in this Symposium. Thanks also to Ron Allen, Tom Brunker, Patricia Cassell, Keith Findley, Roger Koppl, Larry Laudan, Josh Marquis, Dan Medwed, Felicity Murphy, Maurice Possley, Dan Simon, and George Thomas. Maryann Dennis and Felicity Murphy provide excellent research assistance. All views expressed here are mine alone. This research was made possible in part through generous support from the Albert and Elaine Borchard Fund for Faculty Excellence.
} 
4. Requiring All Defense Attorneys to Directly Ask Their Clients, "Did You Commit the Crime?" and Aggressively Investigate Claims of Actual

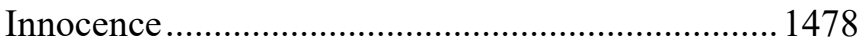

5. Increasing Resources for Indigent Defense Counsel and Prosecutors to Focus on Issues Relating to Actual Innocence 1485

6. More Research on the Frequency and Causes of Wrongful Convictions 1489

\section{INTRODUCTION}

This section of the Symposium focuses on trade-offs that inhere in the criminal justice system, tradeoffs neatly encapsulated in Blackstone's famous ten-to-one ratio of guilty persons who should be allowed escape justice rather than an innocent suffer. Blackstone's aphorism reminds us not only of the importance of ensuring that innocent persons are not convicted, but also that unbounded protections might unduly interfere with convicting the guilty.

A serious attempt to think about these trade-offs comes from Professor Larry Laudan's thoughtful contribution to this symposium ${ }^{1}$ - as well as his more detailed exposition of his thesis in his book ${ }^{2}$ and earlier articles with symposium participant Professor Ron Allen. ${ }^{3}$ For example, here in his symposium piece, Professor Laudan argues for two different burdens of proof at criminal trials: a new clear-and-convincing-evidence standard for trials of known serial offenders and the conventional and higher beyond-areasonable-doubt standard for everyone else. ${ }^{4}$ Laudan highlights the costs of wrongful acquittals ("false negatives") that have to be weighed against the costs of wrongful convictions ("false positives"). In making his calculations, Professor Laudan draws upon Professor Risinger's important article on the subject. $^{5}$

1 See Larry Laudan, Different Strokes for Different Folks: Fixing the Error Pattern in Criminal Prosecutions by "Empiricizing" the Rules of Criminal Law and Taking False Acquittals and Serial Offenders Seriously, 48 SETON Hall L. ReV. 1243 (2018).

2 Larry Laudan, The Law's Flaws: Rethinking Trials AND Errors? (2016).

3 Ronald J. Allen \& Larry Laudan, Deadly Dilemmas, 41 TeXAS TECH L. REV. 65 (2008).

4 Laudan, supra note 1, at 1251-52.

5 Laudan, supra note 1, at 1245 (citing D. Michael Risinger, Innocents Convicted, 97 J. CRIM. L. \& CRIMINOLOGY 761 (2007)); see also LAUDAN, supra note 2, at 54. 
In this Symposium, Professors Marvin Zalman and Keith Findley have both written thoughtful responses to Laudan. Of most interest for my purposes is Zalman's, who contends that the "anti-Blackstonians"including Laudan-improperly reject Blackstone's cautions about the need to have strong safeguards against convicting the innocent. ${ }^{6}$ In his far-ranging article, Zalman says that he writes from an "innocentric" perspective. ${ }^{7} \mathrm{He}$ critiques the views of legal scholars whom he identifies as "antiBlackstonians," arguing that they would "neutralize the theory of prodefendant procedural asymmetry." "Zalman argues that these scholars lack empirical support for their positions or, to the extent support exists, relevant evidence has been ignored.

Curiously, Zalman includes me among the anti-Blackstonians, even though he acknowledges that I "accept[] the Blackstone principle." If I understand his argument correctly, he starts from the fact that my previous writings have properly called attention to the need to consider not only the risk of wrongfully convicting an innocent person, but also need to prevent new crimes that might result when a guilty person escapes conviction. According to Zalman, I would achieve this laudable goal "by neutralizing the theory of pro-defendant procedural asymmetry, by reducing the standard of proof, and by eliminating some procedural protections" and thus it is "no stretch" to describe me as an "anti-Blackstonian."10 Laudan reviews a number of proposals I have made for reforming the criminal justice system, ${ }^{11}$ raising questions about each of them.

In my contribution to this symposium, I respond to both Professors Laudan and Zalman and make two main points. First, in Part I, I turn to Laudan's policy proposal for reducing the number of wrongful acquittals e.g., lowering the prosecution's burden of proof at trial for previouslyconvicted felons to clear and convincing evidence. This proposal is unconstitutional under existing Supreme Court precedents, which interpret the Constitution to require the prosecutor to prove a defendant's guilty by proof beyond a reasonable doubt. And in addition, Laudan has failed to demonstrate that his proposal is cost-beneficial because he has not

6 Marvin Zalman, The Anti-Blackstonians, 48 SETOn HALl L. ReV. 1319 (2018).

7 Id. at 1325 (citing Daniel S. Medwed, Innocentrism, 2008 U. ILL. L. REV. 1549 (2008).

8 Id. at 1324.

9 Id. at 1322 (citing Paul G. Cassell, Freeing the Guilty Without Protecting the Innocent: Some Skeptical Observations on Proposed New "Innocence” Procedures, 56 N.Y.L. SCH. L. REV. 1063, 1065 (2012) [hereinafter Cassell, Freeing the Guilty]).

10 Zalman, supra note 6, at 1324.

11 See Paul G. Cassell, Can We Protect the Innocent without Freeing the Guilty: Thoughts on Innocence Reforms that Avoid Harmful Tradeoffs, in Wrongful Convictions AND THE DNA Revolution: Twenty-Five YeARS OF FreEING THE INNOCENT 264 (Daniel Medwed ed. 2017) [hereinafter Cassell, Can We Protect the Innocent?]. 
persuasively articulated a way to weigh the costs of wrongful convictions against those of wrongful acquittals. But I offer a "friendly amendment" to Laudan's idea. It should be possible to capture almost all of the benefits of his proposal by placing violent felons on extended periods of parole or supervised release - a condition of which would be that they not commit new crimes. Then, when a previously-convicted felon is arrested for a new crime, he could be tried for a parole violation rather than given a new trial. Supreme Court precedent allows parole violations to be tried under a lower burden of proof. And thus, under this approach, the Laudan idea could be operationalized consistently with the Constitution. Reconfigured in this way, there are strong reasons for thinking that the proposal might well be a cost-beneficial way of reducing wrongful acquittals.

In Part II, I challenge Professor Zalman's claim that he is truly writing from an innocentric perspective. Someone proceeding from this vantage should be willing to endorse a criminal justice reform measure if it meets three criteria: first and most important, it reduces wrongful convictions of the innocent; second, it does not reduce (and ideally would increase) the number of guilty persons convicted; and third, it should not significantly impair any other competing values. With these evaluative criteria in mind, Zalman appears to be a mere fair-weather friend of the innocent, as he does not appear to truly privilege innocence over other competing values. In contrast, my reform proposals (which Zalman is reluctant to endorse) reorient the criminal justice system away from adjudicating procedural issues and toward adjudicating substantive issues of guilt or innocence. The truly innocent will benefit in a system that values substance over procedure - and someone who truly holds an innocentric perspective should endorse reforms that move the criminal justice system in that direction.

\section{ANALYZING THE RISKS OF WRONGFUL CONVICTIONS AND WRONGFUL ACQUITTALS}

Properly structuring defendants' rights in our criminal justice system presents the problem of tradeoffs - specifically that in our effort to prevent the innocent from suffering from a wrongful conviction, we might release the guilty through what can be described as a "wrongful acquittal." In this section, I turn to how we might address these tradeoffs. My springboard for discussion is Professor Laudan's proposal in this symposium to reduce the prosecution's burden of proof to convict a particularly dangerous subset of the criminal suspects. 
For "known serial offenders," Laudan suggests that the prosecution should have to prove guilt only by clear and convincing evidence, rather than by the traditional standard of proof beyond a reasonable doubt. ${ }^{12}$ This section makes three points about this idea. First, Laudan's proposal directly creates Blackstonian tradeoffs - additional guilty persons convicted, but at the expense of innocents suffering. His proposal is almost certainly unconstitutional and, perhaps more important for these purposes, is not necessarily desirable under simply cost-benefit calculations. Second, in theory a way to avoid such dilemmas would be to give the criminal justice system more evidence about guilty and innocent suspects. For example, as a thought experiment, giving crystal balls to police officers so that they have more insight into possible guilt or innocence would - for any level of proof - both increases the number of guilty suspects who could be punished and decreases the number of innocents who would suffer. Third, the real world criminal justice system could be reformed in ways that would be the functional equivalent of giving law enforcement crystal balls. For example, we might give the police greater power to search for evidence or to interview suspects-something that is constitutionally permissible for convicted persons who are on parole (the kind of "known serial offenders" that Laudan is particularly concerned about). Building on this insight, I sketch out a "friendly amendment" to Laudan's proposal that would largely retain the benefits he seeks by placing more offenders on parole for longer periods of time-thereby giving police greater power to collect evidence and statements from them. This approach would both avoid the constitutional objection to his proposal and, even more important, reduce the deadly dilemma that creates the most concern about his idea.

\section{A. Laudan's Unconstitutional (and Perhaps Undesirable) Proposal to Change the Burden of Proof at Trial}

Laudan makes the interesting proposal that we should lower the prosecution's burden of proof for trials involving previously-convicted violent felons. Laudan begins his argument by showing that, on "rational analysis," false acquittals are "much more frequent than false convictions."13 On this point I fully agree with him, ${ }^{14}$ and I doubt whether any of the other symposium participants dispute the point. Reasoning from this premise,

12 Laudan, supra note 1, at 1250.

13 Laudan, supra note 1, at 1253.

14 For extended discussion of the rate of wrongful convictions, compare Paul G. Cassell, Overstating America's Wrongful Conviction Rate? Reassessing the Conventional Wisdom About the Incidence of Wrongful Convictions, 60 ARIZ. L. REV. (forthcoming 2018), with George C. Thomas III, Where Have All the Innocents Gone?, 60 ARIZ. L. REV. (forthcoming 2018), with Paul G. Cassell, Jurisdiction-Specific Wrongful Conviction Rate Estimates: The North Carolina and Utah Examples, 60 ARIZ. L. REV. (forthcoming 2018). 
Laudan also notes that a subset of false acquittals - those involving persons he describes as "known serial offenders" - are particularly costly to society. Serial offenders (i.e., recidivists) are likely to commit a disproportionate number of crimes, a fact well established in the criminology literature. ${ }^{15}$ Laudan, for example, estimates that the average serial felon has a recidivism rate $300 \%$ higher than the average non-serial felon. ${ }^{16}$

Based on these well-founded factual premises, Laudan proposes that the prosecution's burden of proof for establishing guilt should be retained for first-time offenders, while for "serial" or second-time offenders, it should be reduced to something approaching clear and convincing evidence. Laudan reasons that the cost of wrongful acquittals is particularly high for the serial offenders, who are particularly likely to commit additional crimes. Accordingly, Laudan reasons that these different risks should be reflected in differing burdens of proof.

Laudan has quite commendably given close attention to the competing tradeoffs, building on important work on this subject with co-author (and Symposium participant) Professor Ronald J. Allen) entitled "Deadly Dilemmas" 17 and his book THE LAW'S FLAWS: RETHINKING TRIAL AND ERRORS? ${ }^{18}$ The key point in these works is that "[w]hile the prospect of convicting or executing a truly innocent person is horrifying, this type of mistake occurs within a highly complicated matrix of relationships where other equally horrifying mistakes go unnoticed in the conventional discourse." 19 Allen and Laudan quite properly remind us that conviction of an innocent person is not the only kinds of tragedy that the criminal justice system must be concerned about. ${ }^{20}$ An ineffective criminal justice system

15 See, e.g., BARRy LATZER, The Rise AND FAll of Violent CRIME IN AMERICA 230-32 (2017).

16 Laudan, supra note 1 , at 1253 . Laudan had previously used higher numbers and had estimated that "every false acquittal enables more than thirty-six crimes (including on average seven violent ones) during the time when, but for the false acquittal, the defendant would have been incapacitated. Larry Laudan, The Rules of Trial, Political Morality, and the Costs of Error: Or, Is Proof Beyond a Reasonable Doubt Doing More Harm than Good?, in 1 OxFORD StUdies In PHILOSOPHY OF LAW 195, 202 (Leslie Green \& Brian Leiter eds., 2011). But cf. Daniel Epps, The Consequences of Error in Criminal Justice, 128 HARV. L. REV. 1065, 109091 (2015) (critiquing this estimate). The 1.2 figure that Lauder uses here strikes me as extraordinarily conservative.

17 Allen \& Laudan, supra note 3; see also Larry Laudan \& Ronald J. Allen, Deadly Dilemmas II: Bail and Crime, 85 ChI.-Kent L. Rev. 23 (2010); Ronald J. Allen \& Larry Laudan, Deadly Dilemmas III: Some Kind Words for Preventive Detention, 101 J. CRIM. L. \& CRIMINOLOGY 781 (2011).

18 LAUDAN, supra note 2.

19 Allen \& Laudan, Deadly Dilemmas, supra note 3, at 68.

20 See Paul G. Cassell, Freeing the Guilty Without Protecting the Innocent: Some Skeptical Observations on Proposed New "Innocence” Procedures, 56 N.Y.L. ScH. L. Rev. 1063 (2011); see also Alec Walen, Proof Beyond a Reasonable Doubt: A Balanced Retributive Account, 76 LA. L. REV. 344, 363-75 (2015). 
can leave criminals free to harm victims and their families, causing tremendous suffering. ${ }^{21}$ As Josh Marquis has cogently observed, "The justice system is far from perfect and has made many mistakes, mostly in favor of the accused. Hundreds, if not thousands, have died or lost their livelihood through embezzlement or rape because the American justice system failed to incarcerate people who were guilty by any definition."22

In their earlier work, Laudan and Allen recognize that some public policy reform measures that reduce the risk of convicting an innocent person may simultaneously increase the risk that a guilty criminal will escape conviction and go on to commit additional violent crimes against additional victims. In this particular paper, Laudan defends his own public policy reform designed to recalibrate the tradeoffs. Unfortunately, his proposal (as he presents it) suffers from two significant problems. First, it is unconstitutional. And second, he has failed to clearly demonstrate that its benefits would outweigh the costs.

\section{The Unconstitutionality of Lowering Burdens of Proof at} Trial

Perhaps Laudan merely intends for his proposal to serve as a catalyst for more robust thinking about burdens of proof, but as a serious policy proposal it is a non-starter. Laudan's proposal is unconstitutional, at least under existing Supreme Court doctrine. The Supreme Court's decision in In re Winship ${ }^{23}$ constitutionalized the prosecution's burden of proof in criminal cases to be beyond a reasonable doubt. As explained in Winship, the reasonable doubt standard "plays a vital role in the American scheme of criminal procedure. It is a prime instrument for reducing the risk of convictions resting on factual error. The standard provides concrete substance for the presumption of innocence - that bedrock axiomatic and elementary principle whose enforcement lies at the foundation of the administration of our criminal law." ${ }^{24}$ Winship also noted that the proof beyond a reasonable doubt standard has deep historical roots, crystalizing in its current phrasing around 1798 and commanding "virtually unanimous

21 See, e.g., Paul G. Cassell, In Defense of Victim Impact Statements, 6 OHIO ST. J. CRIM. L. 611, 629-30 (2009) (collecting citations to examples of victim impact statements).

22 Josh Marquis, The Myth of Innocence, 95 J. CRIM. L. \& CRIMINOLOGY 501, 517-18 (2005)

23 See id. at 11 (discussing In re Winship, 397 U.S. 358 (1970)).

24 In re Winship, 397 U.S. at 363; see also Ake v. Oklahoma, 470 U.S. 68, 78 (1985) ("The private interest in the accuracy of a criminal proceeding that places an individual's life or liberty at risk is almost uniquely compelling. Indeed, the host of safeguards fashioned by this Court over the years to diminish the risk of erroneous conviction stands as a testament to that concern"); Schlup v. Delo, 513 U.S. 298, 325 (1995) ("concern about the injustice that results from the conviction of an innocent person has long been at the core of our criminal justice system"). 
adherence . . . in common law jurisdictions" 25 — a fact of particular power for those concerned about insuring that criminal defendants continue to receive the protections to which they were originally entitled under the Constitution. $^{26}$ Later decisions from the Court have only reinforced the Court's commitment to proof beyond a reasonable doubt. I find myself in full agreement with Professor Findley who, writing in this symposium, also believes Laudan's proposal to be unconstitutional because proof beyond a reasonable doubt is "so thoroughly entrenched in constitutional doctrine that it is inconceivable the courts will abandon it any time soon."27

Perhaps Laudan intends his exercise to be merely a theoretical one, ${ }^{28}$ because he devotes just a few sentences in his paper to addressing this obvious constitutional issue. Against such well-established precedent, Laudan points briefly to the fact that, at sentencing, repeat felons receive longer sentences than first-time offenders without violating due process, suggesting that this demonstrates that a change in the burden of proof at trial would likewise be permissible. But sentencing procedures involve, by definition, defendants who have already been proven to be guilty beyond a reasonable doubt at trial. Lower burdens of proof at sentencing provide no precedent for changing burdens at trial. ${ }^{29}$ Laudan also points to the fact that "affirmative defenses" can be rebutted by the prosecution by proof less compelling than beyond a reasonable double. ${ }^{30}$ But here again, the Supreme Court has been clear that the reason for this treatment of defenses is that the prosecution will have already, by assumption, proven that the defendant guilty of having committed a crime, leaving the only remaining question to be whether to allow some sort of defense to that guilt. ${ }^{31}$ For example, a

25 Winship, 397 U.S. at 361. For further discussion of the history, see, e.g., Anthony Marano, A Reexamination of the Development of the Reasonable Doubt Rule, 55 B.U. L. REV. 507 (1975); Jon O. Newman, Beyond “Reasonable Doubt," 68 N.Y.U. L. REV. 979 (1993); see also Joel S. Johnson, Note, Benefits of Error in Criminal Justice, 102 VA. L. REV. 237 (2016).

26 As discussed below, see infra notes and accompanying text, I have such concerns.

27 Keith A. Findley, Reducing Error in the Criminal Justice System, 48 SETON HaLl L. REV. 1265 (2018).

28 Alternatively, Laudan might believe that Justice Black's dissenting opinion in In re Winship might become ascendant. Winship, 397 U.S. at 377 (Black, J., dissenting). While Justice Black raises some interesting arguments, nothing in recent Supreme Court jurisprudence suggests that the Court will revisit the question.

29 See United States v. Watts, 519 U.S. 148 (1997) (approving as constitutional lower burden of proof at sentencing).

30 Laudan, supra note 1, at 1257.

31 See, e.g., Patterson v. New York, 432 U.S. 197 (1977) (approving burden shifting on manslaughter mitigation of murder because "in each instance of a murder conviction under the present law New York will have proved beyond a reasonable doubt that the defendant has intentionally killed another person, an act which it is not disputed the State may constitutionally criminalize and punish. If the State nevertheless chooses to recognize a factor that mitigates the degree of criminality or punishment, we think the State may assure itself 
defendant may have gunned down a victim in cold-blood - the crime of murder. But society may choose to create an insanity defense, requiring the defendant to prove that he is insane. Treatment of such defenses tells us little about due process principles ungirding trials to determine whether a defendant has committed a crime.

2. Weighing the Costs of Wrongful Convictions Against the Costs of Wrongful Acquittals

Even if we set aside the constitutional deficiency, a second serious problem with Laudan's argument is that it assumes the desirability of changing the burden of proof revolves around a single metric: the harms an erroneously released offender will inflict by committing additional crimes. Relying on articles by Professors John Kaplan and Laurence Tribe, ${ }^{32}$ Laudan believes that it is possible to simply look to the number of wrongfully convicted persons and the number of crimes committed by violent felons to calculate an appropriate burden of proof. Under Laudan's analysis (at least as presented in this symposium ${ }^{33}$ ), the cost of a wrongful conviction is set at 1 and that cost is assumed to be equal to a crime committed by a released felon. ${ }^{34}$ Laudan then adds in the factually-grounded assumption that each released criminal would have committed (at least) 1.2 crimes if not incarcerated. This assumption rests on the fact that criminals have high rates of recidivism and, if not restrained, may commit many (perhaps dozens) of crimes before being caught. ${ }^{35}$ For example, in an earlier article, Laudan estimated that "every false acquittal enables more than thirty-six crimes (including on average seven violent ones) during the time when, but for the false acquittal, the defendant would have been incapacitated." 36

In his explication of the argument here, Laudan uses the quite conservative assumption of 1.2 crimes attributed to a criminal not incarcerated. ${ }^{37}$ With these metrics in place, it becomes a straightforward

that the fact has been established with reasonably certainty.").

32 John Kaplan, Decision Theory and the Fact-Finding Process, 20 STAN. L. REV. 1065 (1968); Laurence Tribe, Trial By Mathematics, 84 HARV. L. REV. 1329 (1971).

33 In fairness to Laudan, he has a book-length defense of some of his proposals in LAUDAN, supra note 2, although it appears that the many of the issues I present here apply equally to his arguments there.

34 See Laudan, supra note 1, at 1250

35 See James Q. Wilson, Thinking About Crime 145-58 (1983).

36 Larry Laudan, The Rules of Trial, Political Morality, and the Costs of Error: Or, Is Proof Beyond a Reasonable Doubt Doing More Harm than Good?, in 1 OXFORD STUDIES IN PhILOSOPHY OF LAW 195, 202 (Leslie Green \& Brian Leiter eds., 2011). But cf. Epps, supra note 16 , at $1090-91$ (critiquing this estimate).

37 Cf. Alfred Blumstein \& Jacqueline Cohen, Characterizing Criminal Careers, 237 SCIENCE 985 (1987) (offenders who had previously been arrested twice were found to have committed between nine and seventeen serious offenses per year free); PETER W. 
mathematical exercise, involving simple division of the harms from wrongful acquittals divided by the harm of wrongful convictions., to determine the optimal standard of proof. ${ }^{38}$ The cost of a wrongful conviction is 2.2 using this metric ( 1 wrongful conviction +1.2 crimes probably committed by the true perpetrator who escaped conviction), while the cost of a wrongful acquittal is 1.2 (the 1.2 crimes that the criminal who escapes justice is likely to go on to commit). Relying on the ratio of 1.2 over 2.2, Laudan concludes that while the cost of a wrongful conviction is marginally higher than that of wrongful acquittal, the net balance (using the methodologies from Professors Kaplan and Tribe) suggests the burden of proof should be around $65 \%$ accuracy - something akin to clear and convincing evidence. ${ }^{39}$

But calculating this ratio requires a much richer assessment of costs and benefits than Laudan attempts here. ${ }^{40}$ For starters, Laudan focuses on individual costs and benefits - i.e., the cost to the person wrongfully convicted. But significant societal costs likely attach to wrongful convictions, such as lack of public confidence in the criminal justice system and perhaps in the government itself. ${ }^{41}$ This lack of confidence may, in turn, create additional instrumental costs, such as the failure of witnesses to come forward to report crimes.

Laudan also needs to more fully consider the interesting argument made by Risinger (among others in a long tradition tracing back to Immanuel Kant) that the State bears a "special responsibility to insure that the innocents that it sweeps up in carrying out its crime-control functions are not convicted"a responsibility that exceeds its obligations to prevent crime that is the "freewill-based choice" of a criminal. ${ }^{42}$ Despite its venerable tradition, this "special-responsibility" argument taken in isolation strikes me as ultimately unpersuasive, at least when applied to the contemporary American society. A more robust assessment of the State's responsibilities is required. For

GREENWOOD, SELECTIVE INCAPACITATION 45 (1983) (median number of burglaries committed by inmates was five per year, but the top ten percent of offenders committed an average of 232 burglaries a year).

38 More precisely, the formula for determining Standard of Proof ( $\mathrm{SoP})$ can be expressed as $\mathrm{SoP}=1 /\left[1+\right.$ (harm $_{\mathrm{F}-} /$ harm $_{\mathrm{F}+}$ ), with the critical ratio being the harms from wrongful acquittal $(F-)$ divided by the harms from wrongful conviction $(F+)$.

39 See Laudan, supra note 1, at 1253

40 See generally Alec Walen, Book Review, (Oct. 2017), http://clcjbooks.rutgers.edu/ books/the-laws-flaws-rethinking-trial-and-errors/. For recent and comprehensive efforts to lay out a theoretical framework for evaluating such tradeoffs, see Epps, supra note 16; Walen, supra note 20.

41 For a helpful discussion of this point, see Walen, supra note 20, at 365-67.

42 Risinger, supra note 11, at 1020. See also Allen \& Laudan, supra note 6, at 81-84 (discussing arguments by Ronald Dworkin and Immanuel Kant); Epps, supra note 16, at $1133-35$. 
example, providing security against crime - particularly for society's most vulnerable members - could also be described as something for which the government has a "special" responsibility. And the need for the government shouldering a special responsibility for pursuing criminals seems much clearer today, given that the government has essentially obtained a monopoly over the American criminal justice apparatus, displacing an earlier system in which private prosecution was a possibility. ${ }^{43}$

But such philosophical debates are unlikely to ever be resolved. So setting them aside, even if we focus exclusively on the quantifiable individual costs of a wrongful conviction, the societal costs of a single wrongful felony conviction are probably higher than the societal costs of single violent crime (setting aside the special case of homicide). To be sure, quantifying the tradeoffs are not simple. Take, for instance, the costs of crime. Writing in this symposium, Professor Findley raised this issue nicely when he explained that "[s]imply counting repeat offenses, even repeat violent offenses, masks wide variations in conduct and harm. A violent crime might be anything from premeditated murder to a barroom tussle, or an unwanted shove or slap." ${ }^{44}$ And on the other hand, the costs of wrongful conviction could well be greater, for reasons articulated nicely, again, by Professor Findley. ${ }^{45}$

But I part company with Professor Findley when he seemingly throws his hands up in despair at the difficulties of assessing the competing costs. ${ }^{46}$ Society is constantly called upon to assess tradeoffs, such as when considering highway safety proposals or new drug approval or any of a variety of other public policy measures. For example, we set speed limits on our nation's interstate highways at around 70 to 80 miles per hour, even though we know that a 35 m.p.h. limit would be much safer. We value the utility of driving quickly over the quality of driving more safely - a decision informed by research on the risks of driving fast and the costs of traffic accidents.

We can make similar decisions with regard to our criminal justice system. One way to quantify the comparative costs or wrongful conviction with wrongful acquittal would be compare jury verdicts (or civil settlements) in cases of wrongful conviction with jury verdicts in cases of criminal assaults. Data published in 1999 suggest, for example, that the loss per

43 See William F. McDonald, Towards a Bicentennial Revolution in Criminal Justice: The Return of the Victim, 13 AM. CRIM. L. REV. 649 (1976); see generally Douglas E. Beloof et Al., Victims in Criminal Procedure 214-83 (3d ed. 2010) (describing current charging practices in American criminal justice, which largely prevent victim-initiated charges)

44 Findley, supra note 27, at 1272.

45 Id. at $1275-77$.

46 Id. at 1277. 
criminal victimization can be quantified as $\$ 2,940,000$ for a murder, $\$ 87,000$ for a sexual assault, and $\$ 19,000$ for a robbery with injury. ${ }^{47}$ A more recent updating of this study estimated the total tangible plus intangible per offense cost for different crimes (in 2008 dollars). The study concluded that the loss per crime victimization can be quantified as $\$ 8,982,907$ for a murder, $\$ 240,776$ for a rape/sexual assault, $\$ 107,020$ for an aggravated assault, and $\$ 42,310$ for a robbery. ${ }^{48}$

How might we weigh these costs against the cost of wrongful convictions? In his longer book on this subject, Laudan makes a modest but ultimately inadequate - effort to quantify the costs of wrongful conviction. Laudan sets these costs at around $\$ 30,000$ per year, based on the costs to society of building a prison to incarcerate the wrongfully convicted person. ${ }^{49}$ Laudan then discounts these costs slightly, given that "a substantial portion of those convicted of violent crimes were unemployed and receiving welfare when they committed their crimes." ${ }^{50}$ But these calculations consider only society's hard or "out-of-pocket" costs to imprisoning the innocent, not the suffering that Blackstone and others have long identified as part of the calculus. Until Laudan makes some sort of effort to consider these costs in his cost-benefit equation, he cannot carry his burden of proof of demonstrating that change is appropriate. ${ }^{51}$

Possible approaches exist for determining the costs of wrongful convictions. For example, data based on jury verdicts could be collected for wrongful conviction cases, where substantial civil judgments (some of them larger than the numbers just cited for victimizations ${ }^{52}$ ) have been entered in favor of those wrongfully convicted.

47 Ted R. Miller, Marc A. Cohen \& Brian Wiersema, Nat'L Inst. Of Justice, Victim COSTS AND CONSEQUENCES: A NEW LOOK 9 tbl. 2 (1996).

48 Kathryn E. McCollister et al., The Cost of Crime to Society: New Crime-Specific Estimates for Policy and Program Evaluation, 108 DRUG \& AlCOHOL DePENDENCE 98, 105 tbl. 5 (2010); see also MiLLER ET AL., supra note 47, at 9 tbl. 2 (using older data to conclude that loss per crime victimization can be quantified as $\$ 2,940,000$ for a murder, $\$ 87,000$ for a sexual assault, and $\$ 19,000$ for a robbery with injury). Cf. David A. Anderson, The Cost of Crime, 7 Found. \& TRENDS IN MicroeCONOMiCs 209 (2012) (estimating total cost of crime in the U.S. at $\$ 3.2$ trillion, more than total health care costs). Similar figures from those quoted in the text come from the RAND Center on Quality Policing, which calculates a cost per murder of $\$ 8,649,216$, per rape of $\$ 217,866$, per aggravated assault of $\$ 87,238$, and per robbery of \$67,277. Paul Heaton, Hidden in Plain Sight: What Cost-of-Crime Research Can Tell Us About Investing in Police, RAND CTR. ON QUality POLICING (2010), https://www.rand.org/content/dam/rand/pubs/occasional papers/2010/RAND_OP279.pdf.

49 LAUDAN, supra note 2, at 77.

50 LAUDAN, supra note 2, at 77.

51 See generally Darryl Brown, Cost-Benefit Analysis in Criminal Law, 92 CAL. L. REv. 323 (2004).

52 Cf. Paul G. Cassell, Too Severe?: A Defense of the Federal Sentencing Guidelines (and a Critique of the Federal Mandatory Minimums), 56 Stan. L. Rev. 1017, 1037-41 (2004) (discussing cost-benefit analysis in federal sentencing based on victimization figures). 
Another approach might be to look at exoneree-compensation systems that have been put in place in various jurisdictions for the wrongfully convicted.$^{53}$ For example, a federal statute provides $\$ 50,000$ for each year spent in the federal system wrongfully incarcerated $(\$ 100,000$ for each year on death row), while various states provide yearly compensation ranging from $\$ 5,000$ per year to $\$ 80,000$ per year. ${ }^{54}$ Other states provide lump sum payments, which can range from $\$ 20,000$ to several hundred thousand dollars. ${ }^{55}$ These figures might be used to help calculate a cost of wrongful conviction, and then a further quantitative refinement of the tradeoffs discussed above would then be possible. ${ }^{56}$

But one other important factor might also need to be entered into the calculation: The general moral culpability of those who have been wrongfully convicted versus those who have been victims of crime. While the innocence literature does not highlight the fact, most of those wrongfully convicted had apparently committed other crimes - either at the time of the crime for which they were wrongfully convicted or earlier - and the previous crime was often associated with the wrongful conviction. For example, prior arrests can produce police photographs that can end up in a photospread to be misidentified. Or prior crimes may incorrectly arouse the suspicion of police detectives.

One prominent illustration of how the wrongfully convicted may have some moral culpability is Anthony Porter. He was convicted of committing a drug-related homicide in Washington Park on the south side of Chicago. But it was apparently difficult for him to present a defense to that charge, because he may have been committing an armed robbery in another part of the park at the same time. He ran from the park, gun in hand, in full view of witnesses. Porter then denied not only the murder, but also being in the park - a lie he maintained until after his convictions were affirmed. ${ }^{57}$

53 See Erik Encarnacion, Backpay for Exonerees, 29 YALE J.L. \& HuMANITIES 245 (2017); Robert J. Norris, Exoneree Compensation: Current Policies and Future Outlook, in Wrongful Conviction and Criminal Justice Reform: Making Justice 289 (Marvin Zalman \& Julia Carrano eds., 2014).

54 Norris, supra note 53, at 291.

55 Norris, supra note 53, at 291.

56 Cf. Cassell, supra note 52, at 1037-41 (discussing cost-benefit analysis in federal sentencing based on victimization figures).

57 See Marquis, supra note 2, at 517. Whether Porter was in fact innocent has been called into doubt by a new documentary movie, A Murder in the Park. The documentary investigates the fact that Porter was released after a Medill Innocence Project investigation obtained a confession from Alstory Simon to the murder-a confession that led to Porter's exoneration and Simon's incarceration. But later Simon's murder conviction was overturned, in part because of the Innocence Project's coercive investigative tactics had tainted the case against Simon. See Jim Stingl, Duped by Medill Innocence Project, Milwaukee Man Now Free, MilwaUkeE J. Sentinel (Nov. 6, 2014), http://www.jsonline.com/news/milwaukee/dupedby-innocence-project-milwaukee-man-now-free-b99386015z1-281852841.html. 
The prevalence of criminal activity by those wrongfully convicted is suggested by a case I recently worked on involving an alleged wrongful conviction of Robert Wilcoxson. ${ }^{58}$ The North Carolina Innocence Inquiry Commission found Wilcoxson to be innocent of a drug-related murder. But it appears that one reason he fell under suspicion was that, at the time of the murder, he was (by his own admission) an armed cocaine dealer making tens of thousands of dollars in the illegal drug trade. ${ }^{59}$ Four other adults also fell under suspicion and were also convicted, wrongfully they have argued. Still, it appears that they may have all have been involved in doing a series of armed robberies at around the same time. ${ }^{60}$ Thus, in this one case, possibly involving multiple wrongful convictions, it appears that all five of the allegedly wrongfully convicted participants were involved in other dangerous crimes apart from the murder for which they were convicted, which made it harder for them to convince authorities of their innocence.

Professor Findley discusses the point about prior convictions in his article, noting that "while wrongful conviction can happen to anyone, those with a prior record are at a significantly higher risk of suffering such an injustice; the rate of exoneration is almost 50 percent higher for those with a criminal record than for those without." ${ }^{\prime 61}$ Findley's suspicions are supported by data from the National Registry of Exonerations. In a recent preliminary tabulation (2017), when the registry had collected 2,101 exonerations-and a total of 1,536 cases with reported data on prior records - $647(42 \%)$ had a prior felony conviction, $163(11 \%)$ had a prior misdemeanor conviction, 30 $(2 \%)$ had a prior juvenile felony conviction, and $13(1 \%)$ had a prior juvenile misdemeanor conviction. ${ }^{62}$ These numbers may be slightly on the low side, since it is possible that the data collected missed some prior convictions known to police. $^{63}$ And it may be easier for a person without a prior conviction to obtain an exoneration (and thus listing in the registry) than one

58 Disclosure: I served as an expert witness for law enforcement officers involved in the civil litigation that resulted from this case, and have served as a similar expert witness in other similar cases.

59 Deposition of Robert Wilcoxson, Wilcoxson v. Buncombe Cty. et al., 129 F. Supp. 3d 308 (W.D.N.C. 2014) (No. 1:13-cv-00224-MR-DSC).

60 Testimony of Damian Mills to N.C. Innocence Inquiry Comm'n, Dec. 18, 2013, at 481-82 (saying that he had been doing a series of breaking-and-enterings with Kagonyera, Williams, Isbell, and Brewton).

61 Findley, supra note 27, at 1283; see also Jon B. Gould et al., Predicting Erroneous Convictions, 99 IowA L. REV. 471, 492 (2014) (finding that prior criminal history influence case outcome in wrongful convictions cases).

62 Email from Samuel R. Gross, Thomas \& Mabel Long Professor of Law, University of Michigan Law, to author (Sept. 30, 2017) (on file with author). These numbers are for the highest prior in each category-i.e., a person with a felony conviction may also have misdemeanor convictions.

63 See id. (noting this limitation, but estimating that that the difference might be in the range of an additional 1 to $2 \%$ ). 
with. ${ }^{64}$ But the general picture of significant prior criminal activity by the wrongfully convicted is clear. And, more broadly, most defendants who stand trial have a criminal record that predates the charged crime. ${ }^{65}$

The point here is not to blame those wrongfully convicted for their plight. The more limited theme is that, when assessing the priority to be given to competing claims between those wrongfully convicted and those who are past (or prospective) crime victims, the victims may have a far stronger claim, at least in the aggregate. Some support for this position comes from a study reporting that, for homicide and assault cases, the majority of the victims had no prior arrest record, while the majority of the offenders did. ${ }^{66}$

A related point can be made about the wrongfully convicted who have pled guilty. Unless the defendant has entered an Alford plea (refusing to plead guilty but preserving his position of innocence), ${ }^{67}$ he has almost certainly committed perjury in entering his plea. Consider, for example, Robert Wilcoxson and Kenneth Kagonyera. ${ }^{68}$ At their guilty plea hearings, both swore under oath that they were guilty, that they were satisfied with defense counsel, and that the other requisites for a knowing and voluntary guilty plea existed. So far as the court records reveal, they also made no effort to enter an Alford plea. In addition, following Kagonyera's decision to plead guilty, he met with the prosecutor and, in the presence of defense counsel made a very detailed statement about his involvement in the murder,

64 I am indebted to Sam Gross for this point.

65 Jeffrey Bellin, The Silence Penalty, 103 IOWA L. REV. 395, 399 (2017) (citing BRIAN A. Reaves, U.S. Dep't of Just. Bureau of Just. Statistics, Felony Defendants in Large Urban Counties, 2009 - Statistical TABles 8, 10-11 (Dec. 2013), https://ww w.bjs.gov/content/pub/pdf/fdluc09.pdf (reporting that $75 \%$ of suspects charged with a felony had a prior arrest, $60 \%$ had a prior felony arrest; $60 \%$ had at least one prior conviction; and $43 \%$ had at least one prior felony conviction)); Theodore Eisenberg \& Valerie P. Hans, Taking a Stand on Taking the Stand: The Effect of a Prior Criminal Record on the Decision to Testify and Trial Outcomes, 94 CoRNELL L. REV. 1353, 1371 tbl. 1 (2009) (study of felony trials in four jurisdictions found $76 \%$ of the defendants standing trial had some kind of criminal record); Martha A. Myers, Rule Departures and Making Law: Juries and Their Verdicts, 13 LAW \& SOC'Y REV. 781, 786-90 \& tbl. 1 (1979) (not reporting percentage but instead providing statistic of an average of 2.7 prior convictions per defendant and that "most defendants had prior convictions"); see also HARRY KALVEN, JR. \& HANS ZEISEL, THE AMERICAN JURY 33 n. 1 \& 145 ( 2 d ed. 1971) (stating in $47 \%$ of the trials in their sample from 1954-1955, the defendant had a prior record).

66 See Arnite A. Varnedoe, Characteristics of Offenders Arrested for Aggravated Assault: A Test of Easterlin's Hypothesis 8-9 (May 1, 1987) (thesis, Atlanta University) (on file with the AUC Robert W. Woodruff Library), http://digitalcommons.auctr.edu/cgi/viewc ontent.cgi? article $=3091 \&$ context=dissertations.

67 See generally Stephanos Bibas, Harmonizing Substantive Criminal Law Values \& Criminal Procedure: The Case of Alford \& Nolo Contendere Pleas, 88 CORNELL L. REV. 1361 (2003); Josh Bowers, Punishing the Innocent, 156 U. PA. L. REV. 1117, 1166 (2008).

68 See N.C. INNOCENCE INQUIRY COMM'N, State v. Kagonyera/Wilcoxson, http://innocen cecommission-nc.gov/cases/state-v-kagonyera-wilcoxson/ (last visited Apr. 25, 2018). 
implicating five other people. ${ }^{69}$ Kagonyera made these statements at his own initiative in an effort to convince the District Attorney that he could provide useful information by testifying against his co-defendants. ${ }^{70}$

To be clear, if Kagonyera and Wilcoxson were in fact innocent, ${ }^{71}$ their guilty pleas were plainly wrongful convictions. And no doubt, their pleas resulted from a plea bargaining process that can be coercive and place considerable pressure on even innocent persons to plead guilty-making the choice of an innocent person to plead guilty in some sense rational. ${ }^{72}$ But particularly where defendants (like Kagonyera and Wilcoxson) have made no effort to enter Alford pleas, ${ }^{73}$ a decision to mislead the Court by pleading guilty produces a wrongful conviction that is, to some extent, the result of illegal choices on their part and therefore entitled to somewhat less weight in social harm calculus. ${ }^{74}$

I would like to see more discussion of and data on these questions, and particularly the extent to which the wrongfully convicted had prior criminal records or were participating in crimes at the time of the offense for which they were wrongfully convicted. (Similar data on victims would be interesting too.) But the critical point here is that Laudan's basic calculations require a much more searching analysis before we can simply assume a cost ratio of 1.2 to 2.2 between wrongful convictions and wrongful acquittals. And without such an analysis, Laudan cannot be said to have carried his burden of proving that his new proposal would be a desirable change.

\section{B. Distinguishing Guilty from Innocent Suspects}

While Laudan's proposal may be flawed, it can usefully serve as a vehicle for thinking more broadly about tradeoffs involved with wrongful convictions. Indeed, Laudan has provided a useful graphical depiction of how we might evaluate competing concerns in Figure 1 in his article, which depicts a set of two bell curves - one for the innocent and one for the guilty. The $x$-axis is the level of apparent guilt and the $y$-axis is the risk of error. ${ }^{75}$

69 Memorandum from Investigator Raymond to Dist. Attorney Moore (Nov. 30, 2001) (memorializing Kenneth Kagonyera's statements made on Nov. 29, 2001) (on file with author).

70 Kagonyera Dep. 134-35:LINE\#s, Jan. 9, 2015, ECF No. (admitting this fact).

71 The North Carolina Innocence Inquiry Commission has found both men to be factually innocent.

72 Compare Bowers, supra note 67, with Stephanos Bibas, Exacerbating Injustice, 157 U. PA. L. ReV. PENNumbra 53, 54 (2008) (responding to Bowers).

73 Currently about 47 states, the District of Columbia, and the federal system authorize Alford pleas. See Bibas, supra note 67, at 1372-73 n.52. However, the extent to which such pleas are effectively available in day-to-day plea negotiations is unclear.

74 It is also possible that they choose to plead guilty to the murder because they were guilty of other serious, violent crimes. See supra notes and accompanying text.

75 To avoid confusing readers, I will follow conventional Cartesian nomenclature and 
One Bell curve - in blue - depicts the distribution of the apparent guilt of guilty criminals. Because these persons are, in fact, guilty, this curve is centered on the right side of the $y$-axis, toward the guilty end. Laudan then depicts a burden of proof for conviction - the beyond a reasonable doubt burden - which Laudan assumes is 96\% apparent guilt. Drawing a vertical line through the Bell curve leaves a substantial area to the left- those guilty persons for whom evidence is insufficient to obtain a conviction, i.e., the false acquittals.

The second Bell curve-in red - depicts the distribution of the apparent guilt of innocent suspects. Because these suspects are, in fact, innocent, this curve is centered on the left side of the $y$-axis, toward the innocent end. Unfortunately, of course, some persons who are innocent may appear to be somewhat guilty. And, indeed, some innocent persons will be so apparently guilty that they will fall to the right of vertical line at the $96 \%$ level of apparent guilt. These are the wrongfully convicted - the innocents who suffer in Blackstone's terms.

One note about the relative sizes of the two shaded areas. The relative sizes show the ratio of the guilty who escape versus the innocent who suffer. For example, if we limit the issue to cases covered by Laudan's figure ${ }^{76}$ and if the criminal justice system is operating at the Blackstonian 10:1 ratio, then the blue area will be ten times larger than the red area. Of course, if the ratios are much larger, then the blue should be much larger as well.

Laudan's blue (wrongful acquittal) area is vastly larger than his red (wrongful conviction) area, even though in some of his writing he appears to suggest that the current system is operating, more dangerously, at below the 10:1 ratio. For example, in his appendix to this symposium piece, with respect to violent crimes, Laudan quantifies the number of false positives (assuming a 3\% error rate) at 10,900 and the number of false negatives at 80,000 , a ratio of about $7.3: 1 .^{77}$ Accordingly, if his charts are going to be

refer to Laudan's horizontal axis as the $x$-axis and vertical axis as the $y$-axis.

76 Laudan's figure appears to be limited to all persons arrested for various crimes. Of course, many arrested and guilty persons will never be successfully prosecuted, not because they will be wrongfully acquitted at trial, but because prosecutors will simply dismiss the case before it proceeds to trial. See infra notes and accompanying text. These persons are nonetheless properly included in Laudan's blue shaded area, because the burden of proof (and other factors) presumably have led prosecutors to be unwilling or unable to successfully pursue conviction. More broadly, however, Laudan's graph fails to capture many cases that involve the guilty escaping prosecution, such as cases in which various procedural rules apart from the burden of proof prevent successful prosecution. The Miranda case may provide a prime example of such rules. See generally Paul G. Cassell \& Richard Fowles, Still Handcuffing the Cops? A Review of Fifty Years of Empirical Evidence of Miranda's Harmful Effects on Law Enforcement, 97 B.U. L. REV. 685 (2017).

76 Laudan, supra note 1.

77 Id. at 1253 , ix. 
link to his empirical data, the ratio of his blue area to red area should be 7.3:1, not the roughly 50:1 ratio that the chart depicts.

Laudan's $x$-axis is also unevenly labelled. It does not appear that he is using a logarithmic scale for apparent guilt, and so the intervals on the $x$-axis should be placed consistently at $10 \%$ intervals - from $10 \%$ to $20 \%$ to $30 \%$. . . to $90 \%$ to $100 \%$, etc. Laudan does not appear to have done this, for reasons that are unexplained.

Laudan also appears to have haphazardly labelled his $y$-axis as "risk of verdicts based upon error." The $y$-axis has nothing to do with risk of error. Instead, the $y$-axis is simply number of defendants - i.e., number of guilty defendants depicted in the blue curve, and number of innocent defendants depicted in the red curve.

With those quibbles aside, one more point becomes important - the relative size of the blue curve and the red curve. Laudan has both curves covering the same total area - which means, apparently, that the criminal justice system is processing the same number of guilty persons as innocent persons. In fact, however, when measured at any point beyond the earliest stages of criminal investigation, the number of guilty persons will vastly exceed the number of innocent persons.

One of the problems with Laudan's graph is that it assumes a static amount of evidence available to police and prosecutors in the criminal justice system. ${ }^{78}$ Given fixed evidence concerning innocent and guilty suspects, the only way to address the problem of false negatives is to change the burden of proof - which inevitably produces the tradeoffs captured in the Blackstone ratio - the "deadly dilemmas" that Laudan (and Allen) have written about so powerfully. But now, as a thought experiment, consider some sort of a change to police investigative procedures that gives police greater insight into the crimes and suspects who come to their attention. Assume, for example, that every police officers becomes equipped with an effective crystal ball, into which the officer could gaze and have, quantitatively speaking, ten percent more evidence about any particular crime. The net effect would be not to change the size of the either of the two Bell curves the curve for the guilty or the curve for the innocent. The police would continue to have the same number guilty and innocent suspects under investigation. Instead, because the police would now have more evidence about any particular suspect, the apparent guilt of the guilty suspects increases - moving that curve to the right. And the apparent innocence of

78 Professor Findley has identified this assumption as a problem with Laudan's article as well. See Findley, supra note 27, at 1272 (Laudan's proposal to change the beyond-areasonable-doubt standard "does nothing to affect the production, access to, and presentation of evidence, which likely represent much more significant variables in determining both the prevalence and distribution of error."). 
the innocence suspect also increases - moving that curve to the left.

The key effect is changes to the two shaded areas. The crystal ball's net effect is to both reduce the number of guilty suspects escaping justice and reduce the number of innocent suspect suffering punishment - the proverbial "win-win" solution. The key insight to the thought experiment is that, because the police have more evidence, they are simultaneously able both to punish more guilty suspects and to avoid punishing more innocent persons.

One way of putting it is that such reforms increase the "diagnosticity" of the system - that is, its ability to distinguish between guilty and innocent persons. Professor Risinger helpfully explained this point, explaining that reform measures for addressing wrongful convictions can be divided into two categories with different moral implications: Some reforms improve the diagnosticity of the system, thereby reducing the incidence of both wrongful convictions and wrongful acquittals. Such reforms - along with reforms that protect the innocent without no reduction in convictions of the guiltyshould be relatively uncontroversial, because (as Laudan aptly puts it) Blackstone would be much happier. On the other hand, some reforms increase the protections for the innocent but do so at the expense of freeing more guilty persons - reforms that are controversial precisely because of the tradeoff involved. ${ }^{79}$

The reader at this point may agree with the thought experiment and related claims as far as they go. But the reader may quickly wonder whether this thought experiment has any real world applications.

One straightforward application is DNA testing capabilities. Consider, using Figure 2, how DNA testing changed the two Bell curves in rape cases. Before DNA testing was available, blood testing might have been able to compare physical evidence left at the scene of the crime with that of a suspect and narrow things down with to, let's say, $10 \%$ of the population. For a guilty suspect, that would mean that the jury would have a high degree of confidence in his guilt, but perhaps not enough to return a guilty verdict (without other evidence). For an innocent suspect, that means a risk of an erroneous conviction, if other evidence (incorrectly) pointed to his guilt. After the arrival of DNA testing, the curve for the guilty suspects moved to the right - their apparent guilt increased with a positive test. And the curve for the innocent suspects moved to the left - the testing reduced the apparent guilt of more innocent suspects through greater discrimination.

79 D. Michael Risinger, The Tragic Consequences of Deadly Dilemmas: A Response to Allen and Laudan, 40 SETON HALL L. REV. 991, 1001 (2010). 
So what is the takeaway from this though experiment? Some readers may say that this proves no more than that we should continue searching for improved crime detection technologies, which are good things for both convicting the guilty and ensuring that the innocent are not punished. But I want to suggest that opportunities for protecting the innocent are more generally available than has been generally appreciated. In fact, we have many quite reasonable opportunities for shifting the innocence Bell curve to the left - without also moving the guilty Bell curve to the left - opportunities that should be endorsed by those who truly come at criminal justice reform from an innocentric perspective. ${ }^{80}$ Indeed, Laudan's proposal itself can be reconfigured slightly to produce at least some improvements in diagnosticity.

\section{Extending Parole to Avoid Wrongful Acquittals}

So far I have criticized Laudan's proposal. But Laudan's proposal is not without its uses. First, Laudan exhibits considerable courage- both in this symposium and elsewhere-in forcing those concerned about innocence issues to think carefully about the arguments that they are raising. Too often, advocates of innocent reforms have not thought through the countervailing concerns. Laudan's proposal forces an explicit consideration of the competing values.

More important, the basic thrust of Laudan's proposal can be salvaged with a few "friendly amendments" to it. With some tweaks, it would be possible for Laudan to present a fully constitutional proposal that would have strong arguments for producing a favorable cost-benefit calculation.

Turning first to the constitutional problem, as discussed earlier, ${ }^{81}$ Laudan's frontal assault on the beyond-a-reasonable-doubt standard for criminal trials is plainly unconstitutional under current doctrine. But because Laudan is attempting to change the burdens of proof not for all accused criminals, but only for a subset - those with a prior felony conviction for a crime of violence ${ }^{82}$ - his proposal can be reconfigured to survive constitutional scrutiny. The reconfiguration relies on the fact that if the previously-convicted felon is still on parole at that time he is accused of the

80 For thoughtful discussion of such issues, see Keith A. Findley, Toward A New Paradigm of Criminal Justice: How the Innocence Movement Merges Crime Control and Due Process, 41 TeX. TeCH L. ReV. 133 (2008).

81 See supra notes and accompanying text.

82 Laudan is somewhat imprecise in defining the group for whom his proposal applies, referring to "serial felons charged with a crime." Laudan, supra note 1, at 1244. For greater precision, I will refer specifically to persons with a previous felony for conviction for a crime of violence. The term "crime of violence" has been subject to considerable adjudication in recent years and bears a precise meaning in many federal and state criminal codes. See, e.g., 18 U.S.C. $§ 16$ (1984) (defining "crime of violence"). 
new crime, the felon's parole could be revoked - and the felon sent back to prison-without a full blown trial under the conventional beyond-areasonable-doubt standard. The United States Supreme Court has recognized that parole revocation proceedings are quite different from ordinary criminal prosecutions and thus the "full panoply of rights due a defendant [at trial] ... does not apply to parole revocations." 83 It is well settled that a "criminal prosecution-governed by the reasonable doubt standard - and a parole revocation hearing are two very different proceedings. In the latter, the Government's 'burden of proof' is considerably less." ${ }^{\prime 84}$

Against that backdrop, it would be possible to obtain most of the benefits of Laudan's proposal by simply converting it to a parole revocation proposal. Here is one way that such a proposal could be operationalized:

83 Morrissey, 408 U.S. at 480.

84 Villarreal v. U.S. Parole Comm'n, 985 F.2d 835, 839 (5th Cir. 1993); see Pierce v. State, Dep't of Soc. \& Health Servs., 646 P.2d 1382, 1386 (Wash. 1982) ("Violation of conditions of parole need not be established beyond reasonable doubt. All that is required is that the Board be satisfied by a preponderance of the evidence that the parolee has breached a condition under which he was granted parole."). 


\section{CASSELL PAROLE EXTENSION PROPOSAL}

1. Any person convicted of a violent felony shall, in addition to any punishment currently provided, be placed on a term of parole for an additional ten years after his release from custody. The conditions of the term of parole shall, at a minimum, require that the person not commit any new violent crime in violation of any federal, state, or local law.

2. Upon a credible allegation that a person has committed a new violent crime in violation of the terms of parole, the person shall be tried at a parole revocation hearing. The person shall generally receive the protections provided at a criminal trial, including the right to be notified of the charges in writing, advance notice of the evidence against him, an opportunity to be heard in person and through counsel regarding the charges, and opportunity to confront and cross-examine witnesses (except for good cause shown), and a decision by a neutral and detached decision-maker. However, the parole revocation determination will be made under the clear and convincing evidence standard.

3. During the period of parole, the person on parole shall be subject to search (and his premises subject to search) upon an articulated ground of suspicion.

4. During the period of parole, the person on parole may be subject to reasonable questioning without prior delivery of Miranda warnings.

5. All other criminal penalties for violent crimes shall be reduced by $5 \%$ [or such other amount as is required to keep the proposal "punishment neutral"-i.e., so that the number of persons in prison for violent crimes does not change due to the enactment of this proposal].

6. The existence of this program shall be widely announced through mass media and in other ways. 
This parole-expansion proposal would require that, after any violent felon's release from prison, he would be placed on parole for ten years and could be sent back to prison if he violated that parole by committing a new violent crime - a violation that would be adjudicated under a clear and convincing standard of evidence, just as Laudan proposes. ${ }^{85}$ As just discussed, at parole revocation hearings, a clear and convincing standard of proof is plainly constitutionally permissible - indeed, most state parole proceedings are resolved under the lower preponderance of the evidence standard ${ }^{86}$ The proposal also provides those accused of violating parole with the constitutionally-required due process safeguards specified by the Supreme Court. ${ }^{87}$

To be sure, the parole-expansion proposal would only apply for the additional ten years after release from prison rather than the (apparently) lifetime application that Laudan's proposal envisions. But given that violent criminals tend to "age out" of criminal activity over time, ${ }^{88}$ an additional tenyear period of parole would likely capture the vast bulk of the crimeprevention benefits of Laudan's proposal.

This proposal also should help improve the diagnosticity of the investigation of crimes, at least to some degree. The proposal allows the state to search a parolee or his premises upon some minimal articulated suspicion. The Supreme Court has already upheld suspicionless searches of parolees as constitutional. ${ }^{89}$ This proposal goes a bit beyond what is constitutionally required, by requiring some articulated reason for the search. And, more important, in allowing police to quickly search parolees and their premises,${ }^{90}$ the proposal should produce more physical evidence of crimes-

85 Because the proposal is triggered by allegations of new crime, it is not fairly characterized as a "preventive detention" proposal. For thoughtful discussion of issues surrounding preventative detention, see Ronald J. Allen \& Larry Laudan, Deadly Dilemmas III: Some Kind Words for Preventive Detention, 101 J. CRIM. L. \& CRIMINOLOGY 781 (2011).

86 See, e.g., People v. Abrams, 158 Cal. App. 4th 396 (Cal. Ct. App. 2007); State v. Harris, No. S0200CR201400075, 2016 Ariz. Super. LEXIS 388 (Ariz. Sup. Ct. 2016); Romero v. People, 179 P.3d 984 (Colo. 2007); Russell v. State, 982 So. 2d 642 (Fla. 2008); People ex rel. Matthews v. N.Y. State Div. of Parole, 447 N.E.2d 689 (N.Y. 1983); Ex parte Doan, 369 S.W.3d 205 (Tex. Crim. App. 2012); State v. Maestas, 997 P.2d 314 (Utah Ct. App. 2000); State v. Brown, 140 A.3d 768 (R.I. 2016).

87 See Morrissey v. Brewer, 408 U.S. 471, 489 (1972).

88 See, e.g., Michael Massoglia \& Christopher Uggen, Settling Down and Aging Out: Toward an Interactionist Theory of Desistance and Transition to Adulthood, 116 AM. J. Soc. $543(2010)$.

89 Sampson v. California, 843 U.S. 547, 857 (2006) ("the Fourth Amendment does not prohibit a police officers from conducting a suspicionless search of a parolee").

90 Searches of parolees' premises does present concerns about invading the privacy of third persons. Tracing out these competing concerns is beyond the scope of this article. But these concerns could be addressed in other ways. For example, the parolee might be required to give notice (as is often done currently) to other occupants of his residence of the existence of this search condition. If this is deemed inadequate protection for third parties, perhaps the 
evidence that would help sort out the guilty from the innocent. ${ }^{91}$

The proposal also helps to collect more statements from potential criminal suspects, by allowing the government to questioning parolees without Miranda warnings. Here again, this approach is entirely consistent with current caselaw, which recognizes that convicted criminals under the supervision of the government may be subject to questioning in various ways without triggering Miranda obligations. ${ }^{92}$

The parole-expansion proposal would thus increase the evidence available to the government during investigating phases of the criminal justice system with regard to a particularly dangerous group of suspects: previously-convicted violent felons. Like newly-discovered DNA technology, expanded evidence collection should help distinguish the guilty from the innocent. The proposal can obviously be criticized as reducing the liberties enjoyed by convicted violent felons. But because this program would be widely advertised in advance, it seems reasonable to respond that such objections are entitled to little weight - the convicted violent felon, after all, would have made a conscious choice to forfeit those liberties.

And what about moving adjudication of crimes away from criminal trials employing beyond-a-reasonable-doubt standards and instead deciding them in parole hearings with mere clear-and-convincing standards? Here some quantification of the competing risk become important. With regard to the criminal justice system currently, the tradeoffs appear to be already tipped decidedly in favor of the accused rather than the prosecution. This would seem to be a strong argument that some modest change in the burden of proof could be possible without unfairly tipping the balance in the government's favor. Indeed, one of the most curious features of Laudan's argument in favor of his proposal is that he rests it entirely on the relative harms of a wrongful acquittal versus a wrongful conviction, the 1.2 versus 2.2 calculus that he derives. But in building from that foundation, Laudan has seemingly forfeited his strongest argument from his earlier research: that, measured in percentage terms, relatively few innocent persons are wrongfully convicted when compared to those victimized by violent criminals. ${ }^{93}$

government's use of an incriminating evidence discovered during such a search could be limited to the parolee himself.

91 See infra notes and accompanying text (discussing this issue at greater length).

92 See Minnesota v. Murphy, 465 U.S. 420, 427 (1984) ("The general obligation to appear before his probation officer and answer questions truthfully did not in itself convert respondent's otherwise voluntary statements into compelled one."). For further discussion of Miranda and wrongful convictions, see infra notes and accompanying text.

93 See Cassell, Overstating America's Wrongful Conviction Rate?, supra note 14. Again, to make clear, each wrongful conviction is an undeniable tragedy for the person who suffers the wrongful conviction. 
Offering an economic perspective on Laudan's proposal, Professor Roger Koppl's thoughtful contribution to this symposium appears to overlook this point. Koppl criticizes Laudan's proposal as hinging, to some degree, on the estimate of a $3 \%$ overall error in the criminal justice system. ${ }^{94}$ But the 3\% figure, while alluded to in Laudan's paper (by cross-reference to his earlier work), is not actually part of his calculation.

More broadly, in Koppl's view, this 3\% error rate figure is too low, although the only additional evidence he offers on this point is a jury verdict replication study from England that is more than forty years old. ${ }^{95}$ The study Koppl relies upon involved "shadow juries" who considered the same evidence that real juries did, ultimately reaching differing conclusions than the real jury in about one out of eight (12.5\%) of all cases. Because $12.5 \%$ is much higher than 3\%, Koppl concludes that the 3\% figure is "too conservative." ${ }^{, 6}$ But even granting that that we might find something like a $12.5 \%$ "error rate" by comparing differing outcomes from two different juries, that differing-outcome rate tells us little about a wrongful conviction rate, a point Koppl himself is careful to flag. ${ }^{97}$ Unless Koppl can show that the juries were considering cases in which a defendant was factually innocent (a proof he does not attempt to make), disagreement over whether the prosecution carried the high burden of establishing guilt beyond a reasonable doubt proves little about innocence issues.

Koppl also offers his qualitative assessment that the $3 \%$ rate is too low, noting quite properly that the earlier research (by Risinger and Gross) upon which the 3\% figure relies might be understated through failure to include all of the wrongful convictions in the samples at issue. ${ }^{98}$ But as Koppl properly acknowledges,${ }^{99}$ there is also the possibility that the samples from which these figures were drawn (involving high stakes capital murder prosecutions) might not be typical of the American criminal justice system. This point provides strong reason for thinking that, as a measure of the overall error rate in the American criminal justice system, the 3\% figure is in fact far too high. ${ }^{100}$

94 Roger Koppl, Comment on Laudan.

95 Id. (citing SARAh McCABE \& Robert Purves, The Shadow Jury AT Work (1974)); see also Roger Koppl \& Megan Sacks, The Criminal Justice System Creates Incentives for False Convictions, 32 CRIM. Just. ETHICs 126, 131-32 (2013) (discussing McCabe and Purves study).

96 Koppl, supra note 94.

97 See id. ("This figure is an average overall error rate for the study and not a rate of false convictions").

98 Id.

99 Id.

100 Professor Thomas and I both explore the subject of the wrongful conviction rate in three recent separate articles, all of which provide a wrongful conviction rate well below $3 \%$. See supra note 14 . 
Professor Gross has explained the reason for thinking that capital murder cases might produce higher error rates, noting that in murder cases there is "extraordinary pressure to secure convictions for heinous crimes" as well as the difficult of investigating crimes without victims available to testify. ${ }^{101}$ Police also devote tremendous resources to solving murder cases, unlike other crimes of violence. ${ }^{102}$ The net result of these factors may well be that the risk of a wrongful conviction is, somewhat paradoxically, greater for more serious crimes than for less serious crimes.

Such risk factors for wrongful conviction are absent in typical criminal investigations for less serious (and more prevalent) violent crimes. The criminology literature persuasively documents that even serious reported crimes often receive only superficial attention from investigators. ${ }^{103}$ If information uniquely identifying the perpetrator is unavailable when the crime is first reported, the perpetrator by and large will never be subsequently identified. ${ }^{104}$ Generally speaking, "if a suspect is neither known to the victim nor arrested at the scene of the crime, the chances of ever arresting him are very slim." 105 One widely-cited study reported that for ten aggravated assault cases, all ten were solved by "routine initial ID" and none were solved by more extended techniques such as a picture ID lineup, interrogation, finger prints, or other investigation ${ }^{106}$ - the types of complex investigations that can produce wrongful convictions. A much larger sample of cases in Kansas found that of aggravated assault cases which we solved, $94 \%$ were solved through such routine initial identification. ${ }^{107}$

The fact that the aggravated assault cases police solve are solved rapidly helps paint of picture of what typical cases prosecuted in the criminal justice system look like. They are probably bar room fights or escalating domestic violence situations, where determining "who dunnit" is not the question. Taking error rates from complex rape-murder investigations and applying them to these kinds of simple cases will invariably and significant overstate the number of wrongful convictions.

101 See Samuel R. Gross et al., Exonerations in the United States, 1989 through 2003, 95

J. CRIM. L. \& CRIMINOLOGY 523, 532 (2005)

102 Id. at 542.

103 John E. Eck, SOlving Crimes: The Investigation of Burglary AND RobBery 16 (1983).

104 Id. (citing Peter W. Greenwood \& Joan Petersilia, The Criminal Investigation

Process - Volume 1: SumMary AND Policy IMPLiCATIONS (Rand 1975)).

105 PRESIDENT'S COMM'N ON LAW ENFORCEMENT AND ADMINISTRATION OF JUSTICE, TASK FORCE REPORT: SCIENCE AND TECHNOLOGY 8 (1967).

106 Peter W. Greenwood, Jan M. Chaiken, Joan Petersilia \& Linda Prusoff, 3 ThE CRIMINAL INVESTIGATION PROCESS: OBSERVATIONS AND ANALYSIS 66-77 (1975).

107 Id. at 77. 
To take one illustration of this point, consider manslaughter cases-i.e., cases in which the defendant concedes that he killed the victim but argues that he was provoked or was acting self-defense. In such cases, the wrongful conviction rate-specifically the "wrong man" conviction rate-is $0.00 \%$. Thus, just as Risinger was able to compute an error rate for a "significant subset of cases" in the criminal justice system (capital rape-murder cases in the $1980 \mathrm{~s}),{ }^{108}$ it is possible to even more precisely calculate an error rate for a much larger number of cases: manslaughter cases, where the error rate is $0.00 \%$ and the factually innocent run no risk at all. This "subset" of cases vastly outnumbers the subset Risinger was examining. By some measures, manslaughter convictions are about as frequent as murder convictions ${ }^{109}$ (and capital murder convictions are, of course, a tiny fraction of all murder convictions).

Stranger crimes (like the ones Risinger was examining) are far and away the most likely areas for wrongful convictions. ${ }^{110}$ For example, the most common cause of wrongful convictions-eyewitness misidentification-is, according to Professor Gross, "almost entirely restricted to crimes committed by strangers." 111 In contrast, most aggravated assaults are not committed by strangers. And even among the "stranger" cases in aggravated assault cases, "who dunnit" issues will not always be present - such as when a drunken man at a bar gets in a fight and is tackled by the surrounding patrons. ${ }^{112}$

In giving short shrift to such issues, Professor Koppl offers no sound reason to credit his speculation that the error rate in the American criminal justice system might be higher than $3 \%$. And, as an economist who has given paid close attention to costs and benefits in other important articles, ${ }^{113}$ it is somewhat surprising that here (perhaps due to the inherent brevity of symposium responses) he offers little discussion of the other side of the equation: the cost of wrongful acquittals and related victimization.

108 Risinger, supra note 6, at 767.

109 See Samuel H. Pillsbury, Judging Evil: Rethinking the Law of Murder and MANSLAUGHTER n.98 (1998).

110 See Samuel R. Gross \& Barbara O’Brien, 5 J. EMPIRICAL L. STUd. 927, 941 (2008) (raising this point).

111 Samuel R. Gross et al., Exonerations in the United States, 1989 through 2003, 95 J. CRIM. L. \& CRIMINOLOGY 523, 530 (2005).

112 Many aggravated assault cases involve close quarters combat. About $27 \%$ of aggravated assaults involve personal weapons such as hands, fists, and feet and 19\% involved knives or other cutting instruments. See FEDERAL BurEau of InVESTigation, UNiform CRIME REPORTS 21 (2012).

113 See, e.g., Roger Koppl \& Megan Sacks, The Criminal Justice System Creates Incentives for False Convictions, 32 CRIM. J. ETHICS 126 (2013). 
My parole-extension proposal also provides for widespread publicity about the program's existence. From a public policy perspective, following prior announcement of the program, the "cost" to be assigned to a wrongful conviction might be somewhat diminished. After all, a person must typically act with mens rea (a guilty mind) to commit a violent crime. And someone who has made the deliberate choice to commit one violent crime might be said to have freely assumed the risk that he will be wrongfully convicted under a lower, clear-and-convincing evidence standard for a subsequent one. This is not to suggest, of course, that just because someone has been convicted of committing a violent crime they are fair game for being tossed into prison whenever the government wants. But it is to say that, given the prior conviction at a time when the program's existence has been widelypublicized, the weight that society should assign to that person's interest in avoiding wrongful conviction can be fairly regarded as somewhat diminished, at least when compared to the interest of that innocent persons have in avoiding violent victimization. ${ }^{114}$

One final objection to Laudan's proposal is also worth considering. Several commentators here (specifically Lillquist, Findley, and Zalman) have raised the specter of over-criminalization. ${ }^{115}$ These commentators believe that society too readily resorts to prisons rather than other means in its response to crime. And, at least with regard to some of their broader critiques (such as their concerns about overbroad mandatory minimum sentences), I tend to agree with them. ${ }^{116}$

But when applied to Laudan's proposal, these critiques are (at least as articulated here) wide of the mark. Laudan's proposal is aimed not at increasing the severity of punishment but its certainty. He is not proposing to punish convicted criminals more harshly, but rather simply to convict more criminals. There is a wealth of literature demonstrating that deterrence effects stem primarily from the likelihood that a criminal will be punished. ${ }^{117}$ And while there is a wealth of literature on what has been called "overcriminalization" in the American criminal justice system, ${ }^{118}$ that literature does not address the undeniable fact that criminals run an

114 Cf. Allen \& Laudan, supra note 85 , at 802 (““"[W]e should be willing to impose a greater risk on the defendant in the case of a prospective harm than in the case of a harm that has already been done.").

115 Zalman, supra note 6; Findley, supra note 27.

116 See, e.g., supra note 52; Erik Luna \& Paul G. Cassell, Mandatory Minimalism, 32 CARDozo L. ReV. 1 (2010).

117 See James Q. Wilson \& Richard J. Hernstein, CRime AND Human NATURe 397-401 (1985).

118 See, e.g., Paul Larkin, The Extent of America's Overcriminalization Problem, HERITAGE FounD. (May 9, 2014), http://www.heritage.org/report/the-extent-americas-overcri minalization-problem. 
extremely low risk of being punished when they commit a crime. For example, while about six million violent crimes are committed each year, only about 113,000 violent criminals are sentenced each year. ${ }^{119}$ While Laudan's proposal may not be the single most effective way to increase the risk of punishment for crime, ${ }^{120}$ it certainly attempts to take a modest step in that direction.

But fully tracing out the relative costs and benefits of criminal sanctions is well beyond the scope of this symposium piece. A simpler way to proceed is, therefore, to take a page from the idea of "revenue neutral" tax reforms and create a proposal that is punishment neutral. The parole-extension proposal outlined above would involve a 5\% reduction in penalties for first time offenders (or whatever higher or lower percentage might be required) so as to create prison space for repeat offenders. The net effect would be no increase in punishment - but rather redirected punishment against Laudan's "serial" offenders. This might be expected to have some increased deterrent effect. $^{121}$ And because of the enhanced evidence-gathering features of the proposal (e.g., the parole searchers and interviews) the proposal might be expected to increase the certainty of punishment, which (most criminologists agree) is a key to an effective criminal justice system. ${ }^{122}$

Finally, the alert reader will note that while proposing a friendly amendment to Laudan's proposal, I haven not referred to these ideas as "my" proposal. I have simply tried to improve upon Laudan's own proposal, starting from what appear to be his initial premises. Before fully endorsing the idea, I would like to see what others think about the idea-including other participants in this Symposium. But it does seem as though Laudan's initial instinct - that certain measures could be appropriately targeted at repeat offenders - is a sound one that could be constitutionally and desirably implemented.

119 See Cassell, supra note 11, at 1079.

120 My own view on this subject is that modifying the Miranda rules seem likely to be the single best way of increasing the risk that criminals face of punishment when they commit a crime. See Cassell \& Fowles, supra note 76.

121 See Joanna M. Shepherd, Fear of the First Strike: The Full Deterrent Effect of California's Two-and Three- Strikes Legislation, 31 J. LEGAL STUD. 159 (2002).

122 See, e.g., Wilson \& Hernstein, supra note 117, at 397-401. 


\section{AVOIDING THE TRADEOFFS BETWEEN WRONGFUL CONVICTIONS AND WRONGFUL ACQUITTALS}

So far, I have focused on tradeoffs that require some assessment of competing values - the benefit of avoiding a wrongful conviction versus the cost of a guilty criminal going free. The possibility that most innocence reform measures come at the cost of significant tradeoffs cannot be overlooked. One illustration of this point is reforms regarding eyewitness identification - one the most common causes of wrongful convictions. ${ }^{123}$ Many of the reform measures to address the problem appear to carry with them not only the prospect of avoiding misidentifications but also of discouraging accurate identifications. ${ }^{124}$ More broadly, as Professor Chris Slobogin has noted, "[m]ost reformist energy has understandably been focused on reducing wrongful convictions, through improved interrogations techniques, and identification procedures, defense involvement in the investigative process, and the like. Most of these reforms, however, could also increase wrongful acquittals ...."125

For the second part of this article, rather than embark on what would be a complicated effort to precisely quantify tradeoffs for particular reforms, I would like to search for reforms that help protect the innocent without freeing the guilty ${ }^{126}$ - reforms that ought to be relatively uncontroversial, at least for those (including some of the participants in this symposium) who prioritize innocence issues over other values in the criminal justice system. ${ }^{127}$ Here I want to engage arguments advanced in this symposium by Professor

123 The National Registry of Exonerations listed "mistaken witness ID" as the third leading cause of wrongful convictions, trailing only perjury/false accusation and official misconduct. \% Exonerations By Contributing Factor, NAT'L REGISTRY OF EXONERATIONS (Apr. 26, 2018), https://www.law.umich.edu/special/exoneration/Pages/ExonerationsContrib FactorsByCrime.aspx\#.

124 See Steven E. Clark, Blackstone and the Balance of Eyewitness Identification Evidence, 74 AlB. L. Rev. 101 (2011); see also Laurie N. Feldman, The Unreliable Case Against the Reliability of Eyewitness Identifications: A Response to Judge Alex Kozinski, 34 QUINNIPIAC L. REV. 493 (2016). For a helpful summary of the reform possibilities in this area, see Brandon L. Garrett, CONVICTION the InNOCENT: Where Criminal ProseCuTIONS Go Wrong 248-52 (2011).

125 Chris Slobogin, Lesson from Inquisitorialism, 87 S. CAL. L. REV. 699, 704 (2014); see also D. Michael Risinger \& Lesley C. Risinger, Innocence Is Different: Taking Innocence into Account in Reforming Criminal Procedure, 56 N.Y.L. ScH. L. REV. 869, 898 (2012) (problems with eyewitness misidentification are hard to be address because they are "inherent in the phenomenon").

126 I also search for reform that do not reduce punishment for the guilty. Cf. Luna \& Cassell, supra note 116, at 60-74 (arguing for reduction in mandatory minimum sentences, a reform that might not only shorten sentences for the guilty but also reduce pressure on innocent defendants to plead).

127 See, e.g., Daniel S. Medwed, Innocentrism, 2008 U. ILL. L. REv. 1549 (2008). See generally Daniel S. Medwed, Prosecution Complex: America's Race to Convict and ITS IMPACT ON THE INNOCENT (2012). 
Zalman, who claims to write from an "innocentric" position about such issues. Like other thoughtful commentators, ${ }^{128}$ Zalman agrees that it is important to consider both costs and benefits in advancing reform proposals. But Zalman gives inadequate attention to precisely how a conscientious policymaker might ultimately evaluate reform proposals, particularly when proceeding from an innocentric perspective.

In this Part, I discuss two topics. First, I propose a decision rule that might be useful for evaluating reforms proposed for addressing innocence issues. Second, I apply that decision rule to a series of reforms - reform that appear to be "win-win" escapes from the competing tradeoffs.

\section{A. A Decision Rule for Considering Innocentric Criminal Justice Reform}

When considering whether to support or oppose a proposed reform to the criminal justice system, a lot may depend on the perspective that one adopts. Directly linked to the wrongful conviction issues at hand, Professor Risinger has helpfully proffered the labels "Paleyites" and "Romillists" to designate two camps - based on the positions of the eighteenth-century proto-utilitarian Reverend William Paley and the nineteenth-century reformist Sir Samuel Romilly. ${ }^{129}$ As Risinger sees it, Paleyites tend to be concerned that that criminal justice reforms designed to protect the innocent will so hamper convicting the guilty as to be undesirable. On the other hand, Romillists so strongly recoil from the horror of convicting the innocent that they are willing to see changes adopted even if they make convicting the guilty significantly more difficult. ${ }^{130}$

But what if someone adopts an "innocentric" viewpoint on criminal justice? Writing in this symposium, for example, Professor Zalman acknowledges the competing Paleyite/Romillist categories, but chooses instead to identify himself as writing from an "innocentric" perspective. ${ }^{131}$ Perhaps he likes this label, because it allows him to seize the rhetorical moral high ground. To contest Zalman's perspective, would someone have to write from a "guilt-centric" perspective? Risinger's labels had the clear advantage of assigning to each side in the debate a respectable position, particularly since the Reverend Paley was, as Risinger points out, "a man of significant moral courage, an opponent of slavery, and a man who ruined his chances at a bishopric rather than stifle his criticisms of the way the rich had not lived

\footnotetext{
128 See, e.g., Findley, supra note 80, at 134 (arguing that the goals of convicting the guilty and protecting the innocent are not mutually exclusive).

129 Risinger, supra note 5, at 764.

130 See id.

131 Zalman, supra note 6.
} 
up to their moral obligations to the poor."132

In fairness to Professor Zalman, he is able to point to the origins of his label in the influential work of Professor Daniel Medwed. ${ }^{133}$ Medwed argued that "innocentrism, while not manna from heaven, is a bipartisan (indeed, politically 'centrist') issue that deserves a prominent place on the menu of theoretical, doctrinal, and strategic options for those who work in the area of criminal justice."134 While Medwed helpfully identified innocentrism as associated with the "centrality of issues related actual innocence in courtrooms, classrooms, and newsrooms," 135 he never provided a precise definition of the term. Of more importance for this article, Medwed never addressed what to do if the values associated with innocentrism conflicted with other values. To the contrary, Medwed sought to downplay the possibility of conflict, writing that innocentrism "should have a significant place in [criminal justice] discourse, and it can do so in concert with other time-tested criminal law values."136

In picking up Medwed's perspective, Zalman also fails to articulate precisely how an innocentrist would assess other values that might compete with innocence. I am someone concerned about wrongful convictions albeit one who is also concerned about the willingness of some innocence movement members to traffic in "faux science." 137 Accordingly, I want to sketch out a possible innocentric approach for evaluating reform proposals.

Here is one way an innocentrist might proceed in evaluating a reform proposal:

1. Does the proposal reduce the number of factually innocent persons who are wrongfully convicted?

2. If so, does the proposal significantly reduce the number of guilty persons who are properly convicted. If yes, the

132 D. Michael Risinger, The Tragic Consequences of Deadly Dilemmas: A Response to Allen and Laudan, 40 SETON HALl L. Rev. 991, 999 \& n. 29 (2010).

133 See, e.g., Daniel S. Medwed, Innocentrism, 2008 U. ILL. L. REV. 1549. See generally Daniel S. Medwed, Prosecution Complex: AmericA's Race to Convict AND its ImPaCt ON THE INNOCENT (2012)

134 Medwed, supra note 7, at 1572.

135 Id. at 1549.

136 Id. at 1558

137 See, e.g., United States v. Phillipos, 849 F.3d 464, 471-72 (1st Cir. 2017) ("the District Court considered competing analyses of the reliability of Dr. [Richard] Leo's studies and found that there was 'no indication that there is a body of reliable material that constitutes understanding in this area,' and that 'it would introduce the jury ... to a kind of faux science to present Dr. Leo's testimony"'), as clarified on denial of reh'g, No. 15-1716, 2017 WL 3307482 (1st Cir. 2017), cert. denied, 138 S.Ct. 683 (2018). The competing analysis to which the First Circuit refers is my expert testimony for the prosecution. 
innocentrist should determine whether the costs outweigh the benefits. If the costs are too high, then the proposal should be rejected. But if not, for an innocentrist, a presumption should then arise in favor of the proposal.

3. Do any competing values - such as constitutional requirements or other concerns - clearly outweigh the presumption in favor of the proposal that would otherwise protect the innocent.

Of course, this formula does not resolve all issues about which reform proposals an innocentrist should adopt. Many disputes may arise, in particular, at the second step of this process. For example, some innocentrists have proposed increasing the prosecution's burden of proof from the current beyond-a-reasonable-doubt standard to (in certain cases) anabsolute-certainty standard. ${ }^{138}$ While this change would certainly desirably decrease wrongful convictions, the proposal's likely net effect would be to block conviction of virtually anyone tried under this standard. ${ }^{139}$ While many persons - including many innocentrists - would likely find this to be an unacceptably high cost, an innocentrist is certainly free to weigh the competing values as he or she sees fit.

Even better than weighing tradeoffs, of course, would be to find reasonable reforms that do not interfere with successful prosecution, because then no tradeoff between protecting the innocent and convicting the guilty exists. ${ }^{140}$ A true innocentrist should generally be ready to quickly endorse such reforms. But do any such plausible reforms exist?

\section{B. Reforms that True Innocentrists Should Endorse}

As Professor Zalman notes in his appraisal of my earlier articles, I have proposed a number of ideas for reforming the criminal justice system that are designed to reduce convictions of the innocent while increasing convictions of the guilty. Zalman critiques my proposals, ${ }^{141}$ and, if I understand him

138 Tim Bakken, Truth and Innocence Procedures to Free Innocent Persons: Beyond the Adversarial System, 41 U. Mich. J.L. REFORM 547, 574-75 (2008).

139 See Cassell, supra note 9, at 1076-77; but cf. Keith A. Findley, Adversarial Inquisitions: Rethinking the Search for the Truth, 56 N.Y.L. ScH. L. REv. 911, 923 (2012) ("Cassell is correct about [the higher standard impeding conviction], but only if jurors were to apply that high standard of proof rigorously and literally.").

140 See, e.g., Keith A. Findley, Toward a New Paradigm of Criminal Justice: How the Innocence Movement Merges Crime Control and Due Process, 41 TEX. TECH. L. REV. 133, 134 (2008) (arguing that the goals of convicting the guilty and protecting the innocent are not mutually exclusive).

141 Zalman seemingly attempts to strengthen his critique by leveling the ad hominem attack that my proposals "derive from a conservative, crime control model vision" of criminal 
correctly, he cannot bring himself to fully endorse any of them. Of course, Zalman is obviously free to reject my ideas. ${ }^{142}$ But as an examination of his objections will make clear, he does not do so due to innocentric concerns but

justice" that would "depart from the present adversary system." Zalman, supra note 6 . This attack misses the mark.

First, while I have written several law review articles advancing (in specific contexts) "originalist" jurisprudence, such jurisprudence does not equate with being in favor of restricting defendants' rights. To the contrary, one of my first law review articles urged greater double jeopardy protections for criminal defendants to restore protections that had historically existed. See Paul G. Cassell, The Rodney King Trials and the Double Jeopardy Clause: Some Observations on Original Meaning and the ACLU's Schizophrenic Views of the Dual Sovereign Doctrine, 41 UCLA L. REV. 693 (1994) (arguing for expansion of Double Jeopardy protections for criminal defendants). This was no mere academic exercise, as last year, I served as co-counsel for a law professors' amicus brief to the U.S. Supreme Court asking it to reverse current, non-originalist doctrine that restricts defendant's double jeopardy protections - in a case where doing so would involve overturning a defendant's criminal conviction connected to a murder. See Brief of Amici Curiae Law Professors in Support of Petitioner, Tyler v. United States No. 17-5410, 2017 WL 3588214 (Aug. 15, 2017).

Second, Zalman fails to discuss the fact that, in the 2000s, as a judge, I was a leading voice against mandatory minimum sentences. My 75-page opinion decrying the 55-year mandatory sentence that I was forced to give Weldon Angelos was cited repeatedly by those opposing mandatory sentences - and became one of the most-often cited examples of injustice from those sentences. Since leaving the bench, I have continued to press the attack, both in scholarly articles, see, e.g., Luna \& Cassell, supra note 116, and in mass media appearances, see, e.g., Former Federal Judge Regrets 55-Year Marijuana Sentence, ABC News (Feb. 18, 2015), http://abcnews.go.com/US/federal-judge-regrets-55-year-marijuana-sentence/story?i $\mathrm{d}=28869467$. I have also spoken out in favor of increased funding for federal public defenders. See Paul Cassell \& Nancy Gertner, Public Defenders Falls to the Sequester: Steep Budget Cuts Compromise the Justice System and Won't Save Money in the Long Run, WALL ST. J. (Aug. 20, 2013), https://www.wsj.com/articles/public-defenders-fall-to-the-sequester1377039667.

I have also been involved in advocating for rights for victims of crime in the criminal justice process, both in my legal scholarship, see, e.g., Paul G. Cassell, The Victims' Rights Amendment: A Sympathetic, Clause-by-Clause Analysis, 5 PHOENIX L. REV. 301 (2012), and in pro bono legal activities. For example, I represented "Amy" before the U.S. Supreme Court in her efforts to obtain restitution in a child pornography case. Paroline v. United States, 134 S. Ct. 1710 (2014). I have also joined Harvard law professor Laurence Tribe in urging that the U.S. Constitution be amended to add protections for crime victims. See Laurence H. Tribe \& Paul G. Cassell, Embed the Rights of Victims in the Constitution, L.A. TIMES, July 6, 1998, at B7. Because of this heavy involvement in the crime victims movement, I do have concerns about the suffering of crime victims - but expanding rights for crime victims does not equate with restricting rights for defendants. See, e.g., Benji McMurray, The Mitigating Power of a Victim Focus at Sentencing, 19 FED. SENTENCING REP. 125 (2006). In any event, concern for crime victims constitutes a "third model" of criminal process, outside the conventional two models into which Zalman seeks to shoehorn the world. See generally Douglas Evan Beloof, The Third Model of Criminal Process: The Victim Participation Model, 1999 UtAH L. ReV. 289 (1999).

142 Other thoughtful commentators have suggested that my ideas are well worth exploring. See, e.g., Carissa Byrne Hessick, DNA Exonerations and the Elusive Promise of Criminal Justice Reform, 15 OHIO ST. J. CRIM. L. 271, 277 (2017) ("Cassell makes a strong case that, in a system with severely constrained resources, vindicating constitutional rights comes at the expense of protecting the innocent from conviction."). 
rather due to the priority he would assign to other competing values. As a result, it seems only fair to identify him not as a true innocentrist, but rather as a mere fair-weather friend of the innocent. And others who give high priority to innocence should not be persuaded by his concerns.

1. Abolishing the Fourth Amendment Exclusionary Rule, and Consequently Shifting Defense Resources Away from Litigating Purely Procedural Claims

My writings argue that, if we want the criminal justice system to prioritize the issue of innocence, then a good start would be to reform the Fourth Amendment exclusionary rule. ${ }^{143}$ Abolition of the rule and replacing it with a system of civil damage remedies has been advocated by such distinguished legal figures as Chief Justice Warren Burger, ${ }^{144}$ Dallin Oaks, ${ }^{145}$ Akhil Amar, ${ }^{146}$ Bill Pizzi, ${ }^{147}$ and Paul Robinson. ${ }^{148}$ The classic argument for ending the exclusionary rule is that the rule sets criminals free because the constable has blundered. ${ }^{149}$ But more subtle, and in many ways more pernicious, defects to the exclusionary rule exist. Under a regime that allows the "deliberate exclusion of truth from the fact-finding process," 150 defense efforts will inevitably gravitate toward issues involving the validity of evidence collection rather than toward the evidence itself. Professor William Stuntz perhaps most famously made this point in his writings, explaining how a system with limited resources that emphasizes procedure over substance will give short shrift to factual claims of innocence. ${ }^{151}$ Stuntz was cautious in his argument. As he explained, the current system does not simply involve a direct tradeoff, but rather "places substantial pressure on [defense] counsel to opt for the procedural claim rather than the (potential) substantive one." 152 But Stuntz's bottom-line conclusion seems unassailable: there is some tradeoff in the current regime favoring procedural

143 Cassell, Freeing the Guilty, supra note 9, at 1087-88; Cassell, Can We Protect the Innocent, supra note 11, at 274-75.

144 See Stone v. Powell, 428 U.S. 465, 500-01 (1976) (Burger, C.J., concurring).

145 See Dallin H. Oaks, Studying the Exclusionary Rule in Search and Seizure, 37 U. CHI. L. REV. 665, 739-40 (1970).

146 See Akhil Reed Amar, The Constitution and Criminal Procedure 40-45 (1997).

147 See William T. Pizzi, Trials Without Truth: Why Our System of Criminal

Trials Has Become an Expensive Failure and What We Need to Do to Rebuild It (1999).

148 Paul H. Robinson \& Michael T. Cahill, Law Without Justice: Why Criminal Law Doesn't Give People What They Deserve (2006).

149 People v. Defore, 150 N.E. 585, 587 (N.Y.1926).

150 Stone v. Powell, 428 U.S. 465, 496 (Burger, C.J., concurring).

151 William Stuntz, The Uneasy Relationship Between Criminal Procedure and Criminal Justice, 107 YALE L.J. 1, 37-40 (1997).

152 Id. at 40. 
claims over substantive ones.

Given these trade-offs, those with an innocentric view of the world should be the first to jump on the replace-the-exclusionary-rule-with-civildamages bandwagon. Surely the experience of the rest of the world suggests that the exclusionary rule is not the only way to restrain police abuses. ${ }^{153} \mathrm{~A}$ damages regime can be crafted to fully (and better) protect Fourth Amendment rights, just as we rely on damages regimes to protect other civil liberties, such as our First Amendment rights. ${ }^{154}$

Zalman responds at length to my arguments but, tellingly, his response does not focus on their merits-i.e., whether abolishing the exclusionary rule would be desirable for innocent suspects enmeshed in the system. Indeed, Zalman begins his critique by conceding that, "[a]s a matter of logic, eliminating the Fourth Amendment exclusionary rule cannot lead to wrongful convictions, because possession of contraband signals guilt ...."155 Moreover, Zalman argues - as many of the rule's critics have contended - that "[o]ne consequence of the exclusionary rule is widespread police perjury covering illegal searches." ${ }^{156}$ Given that such misconduct can easily lead to a wrongful convictions ${ }^{157}$ one would think that a reduction would, from an innocentric perspective, highly desirable. Zalman then argues that "corrupt drug law enforcement" has led to the conviction of innocent persons, pointing to the Rampart scandal in Los Angeles and similar miscarriages of justice elsewhere. ${ }^{158}$ But after running through the disturbing particulars of these cases, Zalman readily admits that "[t]hese corrupt and blatant Fourth Amendment violations were undeterred by the exclusionary rule, providing an occasion to rethink the control of illicit police behavior with methods that go beyond the rule." ${ }^{\text {"159 }}$ Precisely! Part of my argument was that a damages regime for protecting Fourth Amendment rights could be crafted that would be stronger than the exclusionary rule - and Zalman could have helped advance the discussion by endorsing it.

153 See Roper v. Simmons, 543 U.S. 551, 624 (2005) (Scalia, J., dissenting) (noting that when adopted, the exclusionary rule was "unique to American jurisprudence" and that "a categorical exclusionary rule has been "universally rejected' by other countries"); see also William T. Pizzi, The Need to Overrule Mapp v. Ohio, 82 U. Colo. L. REv. 679, 717-29 (2011) (discussing limited use of exclusionary remedies in Canada, New Zealand, England and Ireland).

154 See Akhil Amar, The Constitution and Criminal Procedure 27-29 (1998) (explaining why the exclusionary rule is a bad way to deter police misconduct compared to a civil damages regime).

155 Zalman, supra note 6, at 1383 (quoting Zalman \& Grunewald, supra note 203, at 252).

156 Zalman, supra note 6, at 1383 (quoting Zalman \& Grunewald, supra note 203, at 252).

157 The National Registry of Exonerations identifies "official misconduct" as a contributing factor in 52\% of all the cases included there. \% Exonerations, supra note 123 .

158 Zalman, supra note 6, at 1384.

159 Zalman, supra note 6 , at 1384 . 
Zalman also contends that "the Supreme Court's virtual 'drug exception' to the Fourth Amendment" 160 has "indirectly" led to the conviction of "thousands" of innocent persons for drug crimes. ${ }^{161}$ If I understand the argument correctly, Zalman believes that the Supreme Court has played "an enabling role" in allowing drug prosecutions to proceed. But one could just as easily assert that the Supreme Court has played an "enabling role" in allowing innocent persons to be convicted of rape by allowing prosecutions for sex offenders to proceed. To be sure, one can criticize aspects of the war on drugs, as I have at length elsewhere. ${ }^{162}$ And one can even make the argument that drug prosecutions should cease. But reducing the number of criminal indictments is not truly an innocence-based reform. One could just as easily propose invalidating any criminal charges prosecutors file on a Monday (rather than the other four weekdays), and then take credit for a $20 \%$ reduction in wrongful convictions. Arguments against the existence of certain crimes, however well-founded they may be, are not arguments about how to structure our criminal justice system to protect the innocent once we have decided how many crimes should be encompassed in the criminal code. And, of course, issues surrounding the exclusionary rule are not confined to the drug cases, but readily extend more broadly to other cases involving possession of contraband or other evidence-e.g., firearms - cases which extend to serious crimes of violence. These are areas where the case for abolishing the exclusionary rule are at their zenith, ${ }^{163}$ and yet Zalman avoids commenting on them.

Ultimately, by refusing to endorse abolition of the exclusionary rule, Zalman can stay in good graces with other like-minded liberals. ${ }^{164}$ But he reveals himself to be a mere fair-weather friend of innocence. If Zalman were a true innocentrist, he should first analyze whether the proposed

160 For support for the idea that an exception exists, Zalman cites several law review articles, most of which are quite dated. This conveniently allows him to avoid discussing the fact that the Supreme Court has recently handed down a number of decisions in drug cases, vigorously upholding Fourth Amendment rights. See, e.g., Rodriguez v. United States, 135 S. Ct. 1609 (2015) (prolonging traffic stop to wait for drug detection dog after traffic violation and related safety concerns were addressed violated Fourth Amendment); Riley v. California, 134 S. Ct. 2473 (2014) (searching digital information on a cell phone of arrestee generally requires a warrant); Florida v. Jardines, 569 U.S. 1 (2013) (use of drug detection dog on front porch violates Fourth Amendment); United States v. Jones, 565 U.S. 400 (2012) (installing Global Position System on vehicle violated the Fourth Amendment).

161 Zalman, supra note 6, at 1383.

162 See Luna \& Cassell, supra note 116 (criticizing mandatory minimum sentencing schemes).

163 See John Kaplan, The Limits of the Exclusionary Rule, 26 STAN. L. REV. 1027 (1974).

164 In a reply to my article, Zalman "come[s] out of the ideological closet as a liberal (of sorts)." Marvin Zalman, A Brief Reply to Professor Cassell, 48 Seton Hall L. Rev. 1493 (2018). But cf. Christopher Slobogin, Why Liberals Should Chuck the Exclusionary Rule, 1999 U. ILL L. REV. 363 (1999). 
abolition of the rule reduces the number of wrongful convictions. From Zalman's failure to directly engage my arguments on this point, I conclude that he thinks it does. Zalman could have then proceeded to the second step - noting that abolition of the rule does not impair prosecution of the guilty and therefore, for a true innocentrist, a presumption of desirability arises. And given the reasonable alternatives that could be put in place for the rule (as Zalman himself implicitly concedes), there are no strongly countervailing values that should lead him to reject the proposal. Zalman's refusal to endorse abolition of the rule may be good politics in his field of criminology (which appears to be dominated by conventional "liberal" thinking ${ }^{165}$ ) - but it is hardly good for preventing wrongful convictions.

2. Replacing the Miranda Regime with the Videotaping of Custodial Interrogations

Another reform measure that I proposed was replacing Miranda with videotaping of interrogations. I explained that "those who are most concerned about innocence should be skeptical of the law's current structure, which relies largely on Miranda warnings and waivers to protect against coercive interrogations. As a practical matter, this approach does little to help the innocent and prioritizes litigation about Miranda compliance over litigation about the accuracy of confessions." 166 The Miranda warnings-andwaiver regime is not well suited to addressing false confession issues. As Professor Steven Duke has observed, Miranda "serves mainly to distract lawyers, scholars, and judges from considering the real problem of interrogation, which is how to convict the guilty while protecting the innocent." 167 For example, innocent suspects are most likely to waive their Miranda protections; innocent persons have nothing to hide from the police, and so they almost invariably waive their Miranda rights. ${ }^{168}$ Once they waive their rights, the Miranda procedures do little (if anything) to restrain

165 Last year, two criminologists described the extreme leftward bias of the criminology field: "Evidence of the liberal tilt in criminology is widespread. Surveys show a 30:1 ratio of liberals to conservatives within the field, a spread comparable with that in other social sciences. The largest group of criminologists self-identify as radical or "critical." These designations include many leftist intellectual orientations, from radical feminism to Marxism to postmodernism." John Paul Wright \& Matt DeLisi, What Criminologists Don't Say, and Why, CITY J., (N.Y. 2017), https://www.city-journal.org/html/what-criminologists-dont-sayand-why-15328.html. Interestingly, while Zalman thinks it relevant to identify my "vision" of the criminal justice system as being "conservative," see Zalman, supra note 6, at 1357, he does not trouble to identify even a single one of his other sources as having a "liberal" vision.

166 Cassell, Protecting the Innocent, supra note 11, at 275.

167 Steven B. Duke, Does Miranda Protect the Innocent or the Guilty?, 10 CHAP. L. ReV. 551, 566-67 (2007); see also Ronald J. Allen, Miranda's Hollow Core, 100 Nw. U. L. Rev. $71(2006)$

168 See Cassell, supra note 85, at 539-40. 
police questioning, a point that seems to be generally accepted. ${ }^{169}$

Miranda's procedural requirements (like those of the Fourth Amendment exclusionary rule, just discussed) also shift defense attorney time and attention away from claims of innocence. ${ }^{170}$ Miranda has also caused trial judges to turn away from questions of the reliability of confessions and focus on questions about police compliance with the Miranda rules. ${ }^{171}$ Again as Professor Duke has explained, not only is Miranda "virtually useless", but it "replaced a vibrant and developing voluntariness inquiry that took into account the vulnerabilities of the particular suspect as well as the inducement and conditions of the interrogation." 172 The bottom line is that "not only has Miranda allowed the police to disregard actual voluntariness, it has enabled the courts to be equally unconcerned with actual innocence." ${ }^{\text {173 }}$ To ameliorate these harms from the Miranda rules, I have proposed for more than twenty years that Miranda's procedural regime be replaced with a system of modified warnings and videotaping of police interrogations. ${ }^{174}$

In addressing my proposals, Professor Zalman begins with an ad hominem attack, stating in his opening sentence that "[r]idding the world of the Miranda decision has been Cassell's life long quest" and quoting a newspaper article calling my efforts "ideologically driven." 175 But after that opening introduction, we learn that Zalman (who, we are left to assume, is not ideologically driven) agrees that it is "wise to rethink some of the police processes addressed by Warren Court decisions." "176 Indeed, Zalman quickly concedes that many "criminal procedure scholars ... think that Miranda and other Warren Court rulings having directed criminal lawyers to argue procedural issues rather than the facts of cases, an argument that clearly has merit." 177 Zalman agrees that I should "commended for having supported the video recording of confessions an early date," something that Zalman believes demonstrates my "desire to effectively curb abusive police practices

169 Christopher Slobogin, Towards Taping, 1 OHIO ST. J. CRIM. L. 309 (2003) (arguing that Miranda has had an "immunizing" effect on deceptive interrogation tactics); OFFICE OF Legal Policy, U.S. DeP'T Of Justice, RePORT to THE AtTORNEY GENERAL ON THE LAW OF PRETRIAl InTERRogation 97-98 (1986), reprinted in 22 U. Mich. J.L. REFORM 437 (1989).

170 Cassell, Can We Protect the Innocent?, supra note 11, at 276.

171 Id.

172 Duke, supra note 167, at 564.

173 Jacobi, supra note 87, at 12.

174 Id.; see also Paul G. Cassell, Miranda's Social Costs: An Empirical Reassessment, 90 Nw. U.L. REV. 387 (1996).

175 Zalman, supra note 6, at 1381.

176 Zalman, supra note 6, at 1381.

177 Zalman, supra note 6, at 1381 (citing William StunTZ, The COLlAPSE OF AMERICAN CRIMINAL Justice (2011). 
while promoting accuracy in the criminal justice process." 178

Zalman next endorses my proposal for videorecording, but only as a supplement to Miranda instead of a substitute. This conveniently allows him to avoid hard questions about tradeoffs. For example, having agreed with me that Miranda has caused defense attorneys "to argue procedural issues rather than the facts of case," one would think that from an innocentric perspective it would necessarily follow that refocusing those defense efforts would be good for innocent defendants. While acknowledging that this argument has "merit," ${ }^{179}$ Zalman never explains why he ultimately rejects it.

Zalman also does not engage another important issue for those concerns about the innocent. As I have argued in a number of articles, good reasons exist for believing that Miranda has significantly hampered the ability of police officers to obtain confessions from guilty criminals. ${ }^{180}$ My most recent extensive article on this subject (co-authored with economist Richard Fowles) appeared a few months ago with new regression equations and other econometric analysis supporting this conclusion. ${ }^{181}$ Zalman does not take sides on this empirical debate, calling it "contentious."182 But if Miranda has reduced law enforcement's ability to obtain confessions, it has not only harmed law enforcement's ability to convict guilty criminals but also the opportunity of innocent individuals to use those confessions to exonerate themselves. ${ }^{183}$ For example, Professor Gross has observed that the number of exonerations resulting from the true criminal confessing declined sometime between the mid-1950s and the early 1970s. ${ }^{184}$ Gross cites among the possible causes the Miranda decision, which "may result in some reduction in the number of confessions." 185 For someone concerned about

178 Zalman, supra note 6 , at 1384

179 Id

180 See, e.g., Paul G. Cassell, Miranda's Social Costs: An Empirical Reassessment, 90 Nw. U. L. REV. 387 (1996); Paul G. Cassell \& Richard Fowles, Handcuffing the Cops? A Thirty-Year Perspective on Miranda's Harmful Effects on Law Enforcement, 50 STAN. L. REV. 1055 (1998); Paul G. Cassell \& Bret S. Hayman, Police Interrogation in the 1990s: An Empirical Study of the Effects of Miranda, 43 UCLA L. REV. 839 (1996). These conclusions are not universally accepted. Compare, John J. Donohue III, Did Miranda Diminish Police Effectiveness?, 50 STAN. L REV. 1147 (1998) (critiquing the validity of the data used to correlate Miranda with diminished clearance), with Paul G. Cassell, Falling Clearance Rates After Miranda: Coincidence or Consequence?, 50 STAN. L. REv. 1181 (1998) (responding to these criticisms).

181 Cassell \& Fowles, supra note 76.

182 Zalman, supra note 6, at 1381.

183 See Cassell, supra note 85 , at 550-52.

184 Samuel R. Gross, Loss of Innocence: Eyewitness Identification and Proof of Guilt, 16 J. LEGAL STUD. 395, 430-31 (1987).

185 See Cassell, supra note 85, at 51. For reasons to think that Miranda is the most likely cause of this drop in confessions, see Cassell, Miranda's Social Costs, supra note 180, at 285. 
the innocent, getting to the bottom of this debate should be a high priority. ${ }^{186}$

A system that respects the constitutional right against selfincrimination, while at the same time providing greater protection for innocent suspects, could be easily designed. There appears to be wide agreement that video recording interrogations would offer superior protection for innocent suspects than does the current Miranda regime. ${ }^{187}$ A fair number of jurisdictions are moving forward with requiring video recording of at least some interrogations, ${ }^{188}$ although recording is often left to the discretion of police officers or mandated only for very serious crimes.

Zalman (and, more broadly, others in the innocence movement) could help speed the adoption of this important reform if they would highlight the extent to which Miranda does not offer effective protection to the innocent and suggest that we need to replace it with something like videorecording. Of course, coupling a restriction of the Miranda requirements with innocence-protective reforms would be a compromise approach that would be more likely to attract consensus support. Moving in this direction also has the great advantage of not interfering with the conviction of the guilty. It appears that video recording does not greatly interfere with the ability of law enforcement to obtain confessions (although further investigation of this subject is important). And, of course, if the Miranda rules were relaxed or replaced by video recording, there would be an unambiguous boost to prosecution efforts.

From Zalman's innocentric perspective, the first and most important step in evaluating this reform should be whether it reduces wrongful convictions. Of course, that is the centerpiece of my position that videotaping should replace Miranda - rather than be piled on top of it - and Zalman essentially admits that he wants to avoid the question. ${ }^{189}$ But for a true innocentrist, this head-in-the-sand approach would be anathema. Once again, it appears that Zalman is placing other values (and perhaps approval from like-minded criminology colleagues) ahead of protecting the innocent.

186 See generally Paul G. Cassell, Protecting the Innocent from Lost Confessions and False Confessions-and from Miranda, 88 J. CRIM. L. \& CRIMINOLOGY 497 (1998).

187 See Yale Kamisar, On the Fortieth Anniversary of the Miranda Case: Why We Needed It, How We Got It - and What Happened To It, 5 OHIO. ST. J. CRIM. L. 163, 189-90 (2007).

188 See Alan M. Gershel, A Review of the Law in Jurisdictions Requiring Electronic Recording of Custodial Interrogations, 16 RicH. J.L. \& TECH. 9 (2010); Michael S. Schmidt, In Policy Change, Justice Dept. to Require Recording of Interrogations, N.Y. TIMES (May 22, 2014), https://www.nytimes.com/2014/05/23/us/politics/justice-dept-to-reverse-ban-onrecording-interrogations.html.

189 Zalman, supra note 6, at 1381. 
3. Refocus Post-Conviction Relief on Claims of Factual Innocence

Another measure I (and others) have proposed to help the innocent is to refocus post-conviction relief on claims of factual innocence. This proposal stems from the fact that "[o]ne of the great problems for the innocence movement is trying to find the needles in a large haystack - that is, trying to identify innocent persons in a criminal justice system that processes mostly guilty defendants." 190 The empirical basis for this proposal comes from, among other places, two distinguished legal scholars, Joseph Hoffmann and Nancy King. They proposed that federal habeas corpus review of noncapital state court convictions and sentences should, with narrow exceptions, be abolished except for those who couple a constitutional claim with "clear and convincing proof of actual innocence." "191 Relying on a comprehensive study of federal habeas corpus filings, ${ }^{192}$ Hoffman and King found that only seven of the 2,384 noncapital habeas filings in the study $(0.29 \%)$ resulted in a grant of habeas relief, and one of those seven was later reversed on appeal. ${ }^{193}$ Hoffmann and King argued that habeas review of such claims "currently squanders resources while failing to remedy defenseattorney deficiencies. Those resources should be redeployed where they have a more meaningful chance of preventing the deficiencies in the first place." 194 Hoffmann and King's proposal is similar to others that have tried to focus habeas corpus or other post-conviction remedies on protecting the innocent, including Judge Henry Friendly, ${ }^{195}$ Professors John Jeffries, Jr. and William Stuntz, ${ }^{196}$ Professor Samuel Gross, ${ }^{197}$ Professor Stephanie Hartung ${ }^{198}$ and Professor Helen Anderson. ${ }^{199}$ In my earlier writings, I have noted that post-conviction review, by definition, cannot interfere with the

\footnotetext{
190 Cassell, supra note 11 , at 273.

191 Joseph L. Hoffmann \& Nancy J. King, Rethinking the Federal Role in State Criminal Justice, 84 N.Y.U. L. REV. 791, 820 (2009).

192 Nancy J. King et al., Final Technical Report: Habeas Litigation in U.S. DISTRICT COURTS (2007), http://www.ncjrs.gov/pdffiles1/nij/grants/219559.pdf.

193 Id. at 52, 58, 115-16.

194 Hoffman \& King, supra note 53, at 823.

195 See Henry J. Friendly, Is Innocence Irrelevant? Collateral Attack on Criminal Judgments, 38 U. CHI L. REV. 143 (1970).

196 John C. Jeffries, Jr. \& William J. Stuntz, Ineffective Assistance and Procedural Default in Federal Habeas Corpus, 57 U. CHI. L. REV. 679 (1990).

197 Samuel R. Gross, Pretrial Incentives, Post-Conviction Review, and Sorting Criminal Prosecutions by Guilt or Innocence, 56 N.Y.L. ScH. L. REV. 1009 (2011).

198 Stephanie Roberts Hartung, Postconviction Procedure: The Next Frontier in Innocence Reform, in Wrongful CONVICTIONS AND THE DNA REVOLUTION: TWENTY-FIVE YeARS OF FreEING the InNOCENT 247 (Daniel S. Medwed ed., 2017); Stephanie Roberts Hartung, Habeas Corpus for the Innocent, 19 U. PA. J.L. \& Soc. Change 1 (2016).

199 Helen A. Anderson, Revising Harmless Error: Making Innocence Relevant to Direct Appeals, 17 TeX. WeSLEyAN L. REV. 391 (2011).
} 
process of convicting the guilty at trial. Accordingly, post-conviction review offers a particularly promising approach for escaping the tradeoffs identified by Laudan (among others) - it would focus resources on the innocent, not the guilty. ${ }^{200}$

Professor Zalman chooses not to comment on (much less endorse) this important reform, noting only that it is a topic of "current debate among leading habeas scholars." 201 As well it might be. Habeas scholars, writing from differing perspectives, likely will have differing points of view about the need for expanding or narrowing prisoners access to habeas corpus relief. But the important first question for an innocentrist should not be what effect the proposal may have on prisoners' rights, but what effect the proposal has on the innocent. Zalman appears to be remarkably uninterested in this subject, perhaps because it would reduce the effectiveness of his claim that this reform is somehow rooted in a "conservative, crime control model vision of criminal justice" 202 - a vision that (on this topic at least) is shared in important measure, as noted above, by (among others) Judge Friendly and Professors Hoffman, King, Jeffries, Stuntz, Gross, Hartung, and Anderson.

By missing an opportunity to discuss (and perhaps even endorse) postconviction reforms, Professor Zalman misses an important opportunity to help create common ground for proposals that might have a real opportunity of succeeding in legislative bodies. As Zalman and Grunewald point out in their article discussing trial reforms, changes to long-established trial procedures may be highly contentious and lack the institutional support necessary to flourish. ${ }^{203}$ On the other hand, as the list of distinguished scholars recounted above suggests, post-conviction reforms may attract more consensus and be easier to achieve. And given the fact that post-conviction reforms offer an opportunity to largely or entirely escape the kinds of "deadly dilemmas" that inhere in measures to protect the innocent in earlier parts of the criminal justice process, they certainly are worthy of considerable discussion as part of this symposium. Once again, Zalman's failure to do so may suggest that his perspective on the criminal justice system is less "innocentric" than he would have readers believe.

200 Cassell, Can We Protect the Innocent?, supra note 11, at 273. A similar point can be made in support of proposals to give close attention to post-conviction recantation by trial witnesses. See, e.g., Rob Warden, Reacting to Recantations, in WrONGFUL CONVICTIONS AND the DNA ReVolution: Twenty-Five Years of Freeing the InNOCEnT 106 (Daniel S. Medwed ed., 2017).

201 Zalman, supra note 6, at 1378 (citing John H. Blume et al., In Defense of Noncapital Habeas: A Response to Hoffman and King, 96 CORN. L. REV. 4365 (2011)).

202 Zalman, supra note 6, at 1386.

203 See Marvin Zalman \& Ralph Grunewald, Reinventing the Trial: The Innocence Revolution and Proposals to Modify the American Criminal Trial, 3 Tex. A\&M L. Rev. 189, $256(2015)$ 
4. Requiring All Defense Attorneys to Directly Ask Their Clients, "Did You Commit the Crime?" and Aggressively Investigate Claims of Actual Innocence

As I have argued in my earlier writings, a critical resource in the effort to prevent wrongful convictions is defense attorneys. ${ }^{204}$ Yet much innocence literature seems to focus attention on prosecutors as the ultimate source of problems. ${ }^{205}$ For example, Professor George Thomas has recently called prosecutors "the thin last line protecting the innocent." 206 And Thomas is surely right that prosecutors have critical steps they can take to reduce wrongful convictions, such as by fully discharging their Brady obligations to produce exculpatory evidence (a point I have pressed elsewhere). ${ }^{207}$

But recent reform efforts have largely overlooked what may be an even more important bulwark against false convictions: defense attorneys. While occasionally innocence reformers will make a nod to defense attorneys as potential cause of wrongful convictions, ${ }^{208}$ they rarely include defense attorneys as part of the cure. And yet, if we are truly looking for a last line of defense against wrongful conviction, defense attorneys seem like strong candidates. They have direct access to the defendant, as well as a constitutional right to resources to conduct an adequate defense. ${ }^{209}$

Naturally, one can debate whether defense attorneys actually end up receiving adequate resources ${ }^{210}-\mathrm{a}$ subject $\mathrm{I}$ turn to in the next section. Additionally, one can argue that judges and others simply turn a blind eye to incompetent defense lawyers, allowing them continue to practice their trade. $^{211}$ But unfortunately, another significant problem is simply the mindset of the defense bar toward the question of whether their clients are in fact guilty. This outlook has been aptly described as one of "staggering

204 Cassell, Freeing the Guilty, supra note 9, at 1092-94; Cassell, Can We Protect the Innocent, supra note 11, at 277-80.

205 See, e.g., Dana Carver Boehm, The New Prosecutor's Dilemma: Prosecutorial Ethics and the Evaluation of Actual Innocence, 2014 UTAH L. REV. 613 (2014).

206 George Thomas, Prosecutors: The Thin Last Line Protecting the Innocent, in Wrongful Convictions and the DNA Revolution: Twenty-Five Years of Freeing the INNOCENT 208 (Daniel Medwed ed. 2017).

207 See, e.g., Cassell, supra note 9, at 1084-86.

208 See, e.g., Zalman, supra note 6 (noting the ineffective assistance of counsel is on the "canonical" list of causes of wrongful conviction but not otherwise discussing the issue). See also infra notes and accompanying text (collecting statistics on role of defense attorneys in wrong conviction).

209 Ake v. Oklahoma, 470 U.S. 68 (1985).

210 See, e.g., Meredith J. Duncan, "Lucky" Adnan Syed: Comprehensive Changes to Improve Defense Lawyering and Better Protect Defendants"' Sixth Amendment Rights, 82 BROOK. L. REV. 1651, 1710-11 (2017).

211 Id. at $1705-06$. 
indifference." ${ }^{212}$ Defense attorneys simply cannot consider whether their clients are guilty, it is argued, because doing so would impair the quality of the representation they provide. ${ }^{213}$ And, more broadly it is argued, focusing on innocence issues may distract society from dealing with mass incarceration and other issues associated with the guilty. ${ }^{214}$

Approaching this subject from an innocentric perspective, however, we would certainly want defense attorneys to focus on (among other things) the factual innocence of their clients. To address the lack of attention to innocence, I proposed that we could reorient defense counsel by simply requiring them to ask their clients about the subject. As remarkable though it may sound, many defense attorneys do not directly ask their clients whether they are guilty of the crime charged. ${ }^{215}$ The literature on defense counsel interviews describes competing approaches. In what has been called the "traditional model," a defense attorney's client is urged to disclose everything about the crime under a pledge of confidentiality. ${ }^{216}$ But a different approach to the interview involves less fulsome disclosures. Under the "selective ignorance" model, a defense attorney consciously avoids obtaining full knowledge of her client's involvement in the crime. ${ }^{217}$ Instead, she will obtain information only about certain useful facts, while avoiding acquiring knowledge about the bedrock issue of the defendant's guilt. An attorney might employ different devices to be selectively ignorant. In one commonly-suggested approach, a defense attorney might never ask the defendant whether he committed the crime, asking the defendant instead to recount only what the prosecution's witnesses are likely to say. ${ }^{218}$

How often do criminal defense attorneys employ the selective ignorance model? Good data are hard to come by, but indications suggest this model is a fairly common approach. For instance, one interviewer of white collar defense attorneys reported that, "[o]f the attorneys I studied, most either said that they sometimes preferred not to get certain facts from a client or showed by their actions that they felt this way." 219

212 Barbara Allen Babcock, Defending the Guilty, 32 CLEV. ST. L. ReV. 175, 180 (1983).

213 See id.; see also Margaret Raymond, The Problem with Innocence, 49 CLEV. ST. L. REV. 449 (2001).

214 Abbe Smith, In Praise of the Guilty Project: A Criminal Defense Lawyer's Growing Anxiety About Innocence Projects, 13 U. PA. J.L. \& Soc. Change 315, 329 (2010).

215 Cassell, supra note 9, at 1068-69.

216 See Monroe H. Freedman \& Abbe Smith, Understanding Lawyers' Ethics (3d ed. 2004).

217 Id. at $159-60$

218 See, e.g., id. at 193-94 (discussing suggestion by Professor Geoffrey C. Hazard, Jr. that defense attorneys can avoid the rules against knowingly presenting perjured testimony by proceeding in this fashion).

219 Kenneth Mann, Defending White-Collar Crime: A Portrait of Attorneys at WORK 104 (1985). 
Forcing defense attorneys to truly attempt to learn whether their clients are guilty or innocent would create a real benefit: it would give the criminal justice system one more opportunity to begin sorting innocent defendants from guilty ones through the one person who has the best access to important information - the defendant. It is true, of course, that defense attorneys have difficulties obtaining access to witnesses and other forms of evidence. ${ }^{220} \mathrm{But}$ the barriers to information are not all one-sided. Prosecutors are usually precluded from talking to defendants once legal counsel enters the scene. Yet defendants are obviously in a unique position to provide information that can sort the guilty from the innocent. ${ }^{221}$ If defendants can be induced to provide more thorough information to their attorneys about whether they are innocent or guilty, then the system can more effectively protect against wrongful conviction.

If a defendant claims to be innocent, as a first step defense counsel obviously ought to adequately investigate the claim. Presumably adequate defense investigation of innocence happens in many cases, ${ }^{222}$ regardless of whether a defendant claims to be innocent or guilty. But if some defense attorneys are not squarely raising the innocence issue because they think ignorance is tactically useful, they may end up missing a chance to discover exculpatory evidence that could set a defendant free..$^{223}$

In response to this proposal, Professor Zalman rolls out a big rhetorical cannon, calling my suggestion a "radical threat to the adversary system"224 because my argument relies on the assertion that "[i]nnocent persons ensnared in the criminal justice system have a stronger claim to our attention than do the guilty." 225 Zalman concedes that this positon "might be arguably

220 See Mosteller, supra note 78, at 941-43 (discussing "limited defense access to witnesses and evidence").

221 See Slobogin, supra note 125, at 707 ("[T] important source of information about events relating to the offense.").

222 But cf. Ion Meyn, Discovery and Darkness: The Information Deficit in Criminal Disputes, 79 BROOK. L. REV. 1091 (2014) (arguing that certain structural defects in the criminal justice system mean that defense counsel cannot adequately investigate); Andrew D. Leipold, How the Pretrial Process Contributes to Wrongful Convictions, 42 AM. CRIM. L. REV. 1123 (2005) (arguing that current pretrial procedures prevent innocent persons from collecting exculpatory evidence).

223 See Abbe Smith, Defending the Innocent, 32 ConN. L. REV. 485, 510 (2000) (reporting an example of a seemingly delusional defendant blaming thefts on a "chicken man"; defense investigation discovers that man in a chicken suit perpetrated the crimes).

224 Zalman, supra note 6 , at 1385 . It seems indisputable that some changes in the adversary system would benefit innocents. See generally D. Michael Risinger \& Lesley C. Risinger, Innocence Is Different: Taking Innocence into Account in Reforming Criminal Procedure, 56 N.Y.L. SCH. L. REV. 869 (2012) (proposing non-adversarial, joint investigative processes before charges are filed).

225 Zalman, supra note 6, at 1384 (quoting Cassell, Can We Protect the Innocent?, supra note 11 , at 278) (emphasis added). 
correct from an ethical position"; but Zalman argues that this is not "a correct statement of my understanding of the law," 226 although he offers no supporting citation or authority for his legal claim.

Here Zalman reveals his true colors. In response to my reform proposal designed to help innocent defendants ensnared in the criminal justice system, Zalman rejects my view (it bears repeating) that innocents "have a stronger claim to our attention than do the guilty." I can certainly understand someone attacking my position. ${ }^{227}$ But it is difficult to understand the attack coming from someone claiming to be sailing under the banner of "innocentrism." Indeed, it is even more curious that Zalman critiques me while labelling me as an "anti-Blackstonian," apparently not recognizing that the label truly applies more directly to his apparent disagreement with my stance that the innocent have a stronger claim to our attention than the guilty.

But setting labels aside, what about the substantive part of Zalman's argument that requiring defense attorneys to ask their clients whether they are guilty somehow unlawfully interferes with the adversary system? It is hard to see how this would be so. The U.S. Supreme Court has held that "[t]he need to develop all relevant facts in the adversary system is both fundamental and comprehensive." 228 And the Supreme Court has held that defense counsel's duty to investigate extends both to "matters of fact" "and "“points of law." 229 Proceeding from these premises, under current (2015) American Bar Association (ABA) Defense Function Standards, defense counsel has "a duty to investigate in all cases." 230 Likewise, under these standards, "[d]efense counsel's investigative efforts should commence promptly and should explore appropriate avenues that reasonably might lead to information relevant to the merits of the matter, consequences of the criminal proceedings, and potential dispositions and penalties." 231

226 Zalman, supra note 6, at 1385

227 See, e.g., Smith, supra note 214, at 324 ([T]the defendant with the factual innocence story throws every other defendant under the bus.").

228 United States v. Nixon, 418 U.S. 683, 709 (1974); see also Strickland v. Washingtion, 466 U.S. at 691 ("[C]ounsel has a duty to make reasonable investigations or to make a reasonable decision that makes particular investigations unnecessary.").

229 Faretta v. California, 422 U.S. 806, 827 n.35 (1975) (quoting 2 ZEPHANIAH SWIFT, A SYSTEM OF LAWS OF THE STATE OF CONNECTICUT 398-99 (1796)).

230 Fourth Edition of the CRIMINAL Justice StANDARDS FOR THE DEFEnSE FunCtion $\S$ 4-4.1(a) (AM. BAR ASS'N 2015); see also ABA STANDARDS FOR CRIMINAL JUSTICE: ProseCution Function AND Defense Function Third Edition $\S 4-3.2 \mathrm{cmt}$. at 152 (AM. BAR ASS'N 1993), https://www.americanbar.org/content/dam/aba/publications/criminal_justi ce_standards/prosecution_defense_function.authcheckdam.pdf ("The lawyer who is ignorant of the facts of the case cannot serve the client effectively.").

231 Fourth Edition of the Criminal Justice Standards, § 4-4.1(c). 
Of particular relevant to my proposal, under current ABA Defense Functions Standards defense counsel are required to conduct a thorough interview of the defendant to "determine in depth the client's view of the facts and other relevant facts known to the client." ${ }^{, 232}$ The Standards also emphasize that defense counsel "should explain, at an appropriate time, the necessity for frank and honest discussion of all facts known to the client in order to provide an effective defense." ${ }^{233}$

Professor Zalman appears to be entirely unaware of these ethical requirements. Instead, Zalman asserts (again without any supporting authority) that full knowledge of a defendant's information would "make defendants' lawyers structurally subservient to prosecutors, at least by limiting the scope of defense cross-examination of witnesses." 234 Zalman's use of the term "subservient" seems a bit odd here, since prosecutors are presumably subject to the same ethical restraints. But in any event, what Zalman seems to be driving at is that defense attorneys' ignorance may permit them to offer evidence that would otherwise be precluded by the rules of legal ethics. ABA MODEL RULE 3.3 provides that a lawyer shall not "knowingly . . . offer evidence that the lawyer knows to be false." 235

Zalman may be descriptively correct that defense attorneys will be unable to offer false evidence if they know of their client's guilt. But from a normative perspective - and certainly from an innocentric perspective- no good reason exists for giving defense counsel such freedom. It is hard to see what larger societal interest is served by allowing counsel to move forward in ignorance of this important fact.

To be sure, it may be true, as some defense advocates have argued, that a defense attorney can never be entirely sure whether her client is telling the truth when a defendant claims to be innocent. ${ }^{236}$ But requiring defense attorneys to at least ask that basic question would serve the valuable function

232 Id. $\S 4-3.3(\mathrm{c})(1)$.

233 Id. $\S 403.1$ (emphasis added); see also NAT'L LEgAL AID \& DeFENDER Ass'N, Performance Guidelines For CRiminal DefEnse Representation $\S 4.1(\mathrm{~b})(2)$ (2006), http://www.nlada.org/defender-standards/performance-guidelines/black-letter ("[A]n indepth interview of the client should be conducted as soon as possible and appropriate ... The interview with the client should be used to ... seek information concerning the incident or events giving rise to the charge(s) ....”).

234 Zalman, supra note 6, at 1385.

235 ABA Model Rules of Prof'L CONDUCt r. 3.3(a)(3) (AM. BAR ASS'N 2016). But cf. Harry I. Subin, The Criminal Lawyer's "Different Mission": Reflections on the "Right" To Present a False Case, 1 Geo. J. Legal Ethics 125 (1987) (suggesting that there are, in practice, few limits on the defense).

236 See Robert Mosteller, Why Defense Attorneys Cannot, But Do, Care About Innocence, 50 Santa Clara L. Rev. 1, 41 (2010). Most defendants presumably will admit they are guilty. Cf. Poveda, Estimating Wrongful Convictions, 18 JUST. QUART. 689, 701 (2001) (noting that about $15 \%$ of convicted inmates claimed to have not committed the crime for which they had been imprisoned, implying an $85 \%$ admission rate). 
of putting this issue squarely out in the open, helping innocent defendants. If we truly want to structure an "innocentric" criminal justice system that gives highest priority to preventing the conviction of the innocent, ${ }^{237}$ defense attorneys must be involved. In fact, defense attorneys-who (unlike prosecutors) have constant and direct access to defendants-may be uniquely positioned to identify a miscarriage of justice before it happens and take steps to prevent it. They are also well-poised to increase the "diagnosticity" of the system, by helping to flag the relatively small percentage of cases in the system genuinely involving factual innocence claims. ${ }^{238}$ And the only "cost" is that defense counsel for some guilty defendants might be limited in the kinds of false evidence they can present at trial-a "cost" (if that is the right word) that society surely ought to be willing to bear to have a system that more accurately sorts the innocent from the guilty.

This is not simply my (allegedly "anti-Blackstonian") view of the competing concerns, but the view of others, ${ }^{239}$ including most notably the American Bar Association. The ABA Standards for Defense Counsel make clear that defense attorneys should not try to maintain a "calculated ignorance" about guilt. The Standards provide that "[w]hen asking the client for information and discussing possible options and strategies with the client, defense counsel should not seek to induce the client to make factual responses that are not true. Defense counsel should encourage candid disclosure by the client to counsel and not seek to maintain a calculated ignorance." 240 These conclusions are fit comfortably with the related ethical rule - upheld by the U.S. Supreme Court - that defense attorneys may not assist their clients in presenting perjured testimony. ${ }^{241}$

237 See Medwed, supra note 41.

238 Cf. W. Tucker Carrington, “A House Divided”: A Response to Professor Abbe Smith's In Praise of the Guilty Project: A Criminal Defense Lawyer's Growing Anxiety About Innocence Projects, 15 U. PA. J.L. \& Soc. CHANGE 1, 23 (2011) (providing an illustration of a case in which defense counsel obtained a dismissal from a prosecutor by sharing exculpatory evidence collected by defense investigators).

239 Tim Bakken, supra note 138, at 853 ("Professor Cassell is rightly concerned with situations where, with winks and nods, defense attorneys acquire enough evidence from their clients to mount a defense, but work assiduously to prevent their clients from saying to their attorneys, 'I killed the victim intentionally and have no defense."').

240 ABA Defense Standards, supra note 230, § 4-3.3(d); see also ABA Standards for Criminal Justice: Prosecution and Defense Function $\S 4-3.2$ (b) (3d ed. 1993) (defense counsel "should not instruct the client or intimate to the client in any way that the client should not be candid in revealing facts so as to afford defense counsel free rein to take action which would be precluded by counsel's knowing of such facts").

241 Nix v. Whiteside, 475 U.S. 157, 167 (1986) (discussing ABA MOdEL CODE OF Prof'L RESPONSIBILITY DR 7-102 (AM. BAR ASS'N 1980), entitled "Representing a Client Within the Bounds of the Law," which provides that "In his representation of a client, a lawyer shall not ... [k]nowingly use perjured testimony or false evidence ... [or] [c]ounsel or assist his 
To be clear, none of this is to suggest that defense attorneys should roll over and play dead if their clients are guilty. Indeed, the ethical rules make clear, for example, that while attorneys generally may not defend an issue "unless there is a basis in law and fact for doing so," this restriction does not apply to "[a] lawyer for the defendant in a criminal proceeding, ... [who] may nevertheless so defend the proceeding as to require that every element of the case be established."242 In light of this fact, Professor Robert Mosteller (among many others) rightly bristles at the suggestion that there should be some sort of "second-class treatment" of defendants who state clearly that they are guilty. ${ }^{243} \mathrm{He}$ explains quite nicely that defense counsel have important duties to perform in the criminal justice system, even when performing the most common duty of defending those who have in fact committed the crimes charged against them. But he interestingly goes on to discuss the idea that perhaps individual defense attorneys - or the criminal justice system more broadly - should try to devote additional resources to cases in which a defendant has a good claim of actual innocence. ${ }^{244}$ Of course, defense attorneys - and the system - are not well-positioned to do this if the defendant is not even asked whether he is in fact innocent.

Requiring defense attorneys to directly ask their clients about guilt or innocence might also have other desirable consequences. The wrongful conviction literature suggests it is unusual for a defense attorney to communicate her specific concerns directly to a prosecutor. ${ }^{245}$ Perhaps this is part of a larger culture of distrust between prosecutors and defense attorneys that appears to afflict at least some jurisdictions. ${ }^{246}$ But direct communication on innocence issues should be strongly encouraged. ${ }^{247}$

It would, of course, be naive to think that simple defense counsel reports to prosecutors could prevent every wrongful conviction of an innocent defendant. But perhaps an unfortunate reason why defense

\footnotetext{
client in conduct that the lawyer knows to be illegal or fraudulent.").

242 ABA Model Rules of Prof’l CONDUCt r. 3.1 (AM. BAR ASs’n 2016).

243 Mosteller, supra note 236, at 7.

244 Id. at 68-69.

245 See Carrington, supra note 238, at 23 (referring to the "unorthodox" approach of a defense team in a murder case sharing exculpatory evidence with the prosecutor).

246 See Lissa Griffin \& Stacy Caplow, Changes to the Culture of Adversarialness: Endorsing Candor, Cooperation and Civility in Relationships Between Prosecutors and Defense Counsel, 38 Hastings Const. L.Q. 845 (2011).

247 Id. at 869. Cf. D. Michael Risinger \& Lesley C. Risinger, The Emerging Role of Innocence Lawyer and the Need for Role-Differentiated Standards of Professional Conduct, in CONTROVERSIES IN INNOCENCE CASES IN AMERICA 123 (2014) (discussing strong "antisignaling" ethic, in which the criminal defense attorney is prevented from signaling to anyone by any means that a client is guilty, and by necessary implication, affirmatively discouraged, and perhaps even prevented, from effectively signaling that there is real reason to believe that the client is in fact factually innocent of the crime, as opposed to being formally "presumed innocent").
} 
attorneys so rarely discuss the issue with prosecutors is that, as Mosteller suggests, defense attorneys simply do not view their job as having much to do with guilt or innocence. ${ }^{248}$ If defense attorneys proceed in this way, they never learn whether they have an innocent defendant for a client as opposed to a guilty one. This agnostic approach may help to avoid burnout on the job or provide stronger feelings of self-worth, as some have argued in justification. ${ }^{249}$ But this strikes me as a cop-out, leading innocence reformers to point fingers at errant prosecutors and rogue police officers while too often ignoring the role of ignorant defense attorneys. If we truly wish to leave no stone unturned in our efforts to prevent conviction of the innocent, it is time to broaden our perspective to include defense attorneys as those who have special responsibility - and special abilities - to prevent wrongful convictions. $^{250}$ Those who genuinely adopt an innocentric perspective should have little difficulty with this conclusion.

\section{Increasing Resources for Indigent Defense Counsel and} Prosecutors to Focus on Issues Relating to Actual Innocence

On the issue of wrongful convictions, the elephant in the room is little discussed but obvious: money. The root cause of many wrongful convictions is likely insufficient resources devoted to the criminal justice system. Whatever individual causes might be pinpointed in particular cases, more resources would often have enabled defense counsel (or police and prosecuting agencies) to locate persuasive evidence of innocence. ${ }^{251}$ If this diagnosis is correct, then an important part of the true solution to the wrongful conviction problem may be devoting additional resources to the criminal justice system. ${ }^{252}$

248 Mosteller, supra note 236, at 60-64; accord Babcock, supra note 212, at 180.

249 See generally Barbara Allen Babcock, Book Review, 53 GEO. WASH. L. REV. 310, 315 (1984).

250 One way to hold defense attorneys accountable for wrongful convictions would be through civil suits against them. Recent cases seem to be broadening defense liability in this area. See, e.g., Dombrowski v. Bulson, 79 A.D.3d 1587, 1589 (N.Y. App. Div. 2010) (nonpecuniary loss damages are available for criminal defendant's loss of liberty due to attorney malpractice); $c f$. Kevin Bennardo, Note, A Defense Bar: The "Proof of Innocence" Requirement in Criminal Malpractice Claims, 5 OHIO ST. J. CRIM. L. 341 (2007) (proposing that defendants should not be required to prove that they are innocent to proceed with criminal malpractice claims)

251 See Robert Gehrke, If Utah Doesn't Provide Better Legal Defense for the Poor, ACLU May File Lawsuit, SALt LAKE TRIB. (Sept. 20, 2015), http://www.sltrib.com/news/2966774155/if-utah-doesnt-provide-better-legal (discussing case of wrongful conviction in Utah where overworked public defender was apparently unable to obtain alibi witnesses).

252 See, e.g., Alexandra Natapoff, Negotiating Accuracy: DNA in the Age of Plea Bargaining, in WrONGFUl CONVICTIONS AND THE DNA REVOLUTION: TwENTY-FIVE YEARS OF FREEING THE INNOCENT 85 (Daniel S. Medwed ed., 2017). 
Some sense of the funding problem's size comes from data on the association between ineffective assistance of counsel and cases of wrongful conviction. $^{253}$ A 2005 study by the Innocence Commission for Virginia reviewed original court files and interviewed key actors in 11 wrongful convictions cases and found evidence that the defense had fallen short in five of them. ${ }^{254}$ A similar review in New York in 2009 found defense failings in 19 out of 53 cases. $^{255}$

Given the fiscal realities of the world we live in, however, it may be an academic proposal to call for significant new funding for defense attorneys, for example. ${ }^{256}$ At a macro level, the funds devoted to the criminal justice system are probably roughly fixed and not much is likely to change in the near term. ${ }^{257}$ What is needed, then, is to prioritize innocence over other criminal justice expenditures.

Fortunately, for those who truly believe in "innocentrism," there are ways to do this. Each of the four preceding sections would involve a prioritization of cases involving innocent defendants over cases involving guilty one. For example, abolishing the Fourth Amendment exclusionary rule would free up defense resources to be used in litigating other issues, including innocence issues. Once procedural issues regarding the legality of searches are diverted to the civil justice system, the criminal justice system would gain newly-available resources to devote to innocence issues. Instead of filing and litigating these motions having nothing to do with innocence, defense counsel could turn their attention to substantive issues revolving around guilt or innocence. Prioritizing substantive issues over procedural issues is exactly the way the system should be structured - and a way that both increases the chance of convicting the guilty while reducing the chance of convicting the innocent.

253 The data in this paragraph come from Alissa Pollitz Worden et al., Public Defense in an Age of Innocence: The Innocence Paradigm and the Challenges of Representing the Accused, in Wrongful CONVICTION AND CRiminal Justice Reform: MaKing Justice 209, 212 (Marvin Zalman \& Julie Carrano eds., 2014).

254 Id. (citing INNOCENCE COMM'N FOR VA., A VISION FOR JUSTICE: REPORT AND ReCommendations Regarding Wrongful Convictions in the COMMONWEALth of VIRGINIA (2005)).

255 Id. (citing N.Y. State Bar Ass'n, Final Report of the New York State Bar ASSOCIATION'S TASK FORCE ON WRONGFUl CONVICTIONS (Apr. 4, 2009), https://www.nysba .org/wcreport/).

256 See Mary Sue Backus \& Paul Marcus, The Right to Counsel in Criminal Cases, a National Crisis, 57 Hastings L.J. 1031, 1059 (2006); Cassell \& Gertner, supra note 141 (urging that federal public defender funds not be sequestered).

257 See Erik Lillquist, Improving Accuracy in Criminal Cases, 41 U. RicH. L. Rev. 897 (2007) (noting a common assumption that there are fixed resources devoted to criminal justice). 
Responding to my proposal, Professor Zalman first accuses me of "sleight of hand," because I discussed this important issue towards the tail end of my list for reforms rather than the outset. ${ }^{258}$ But I was not trying to bury the lead, but rather to simply arrange them in sequential order. I have employed the same approach here, first discussing ways to divert resources towards the innocent (such as abolishing the exclusionary rule) and then noting here how redirecting resources could be an important step in reducing wrongful convictions.

Zalman also accuses me of "glaring internal inconsistency" in my approach. $^{259}$ The basis for this charge is that I was concerned about a proposal that would have given defendants a largely-unrestrained "right" to demand that police investigate claims of alleged innocence. I explained why such an expansive right for all defendants (both guilty and innocent) would divert "both police and judicial resources into many wild-goose chases." 260

It is appropriate to worry that defendants, armed with a right to demand that police follow up purported leads showing innocence, might malicious send police in the wrong direction. Guilty defendants have nothing to lose by flooding police agencies with leads regarding their innocence. For example, a charged defendant might claim that the "real" criminal was either Able, Baker, or Charlie - and give police some half-baked theory for why each of these persons had committed the crime in question. While the police are busy looking into Able, Baker, and Charlie, of course, they are unable to concentrate their efforts on the defendant. And, of course, all this work forced on the police might simply put pressure on the prosecution to offer the defendant a more favorable plea again.

In contrast, defendants have little incentive to send their own attorneys off in the wrong direction. Defendants surely are aware that time, money, and resources in building the defense case are limited, and they would have no reason to squander them. This is not to say that, occasionally, defendants may have case-specific reasons for misleading their attorneys. Defendants may wish, to protect, for example, other family members or other reasons for being inaccurate with their attorneys. But defendants lack any systemic reasons to ask for defense resources to be expended on running down false leads.

More fundamentally, Zalman fails to appreciate how reforms such as the ones that I am proposing could free up significant resources for the defense. Consider, for example, the proposal to abolish the exclusionary rule. While the percentage of cases in which the exclusionary rule results in

258 Zalman supra note 6, at 1371.

259 Id. at

260 Cassell, Freeing the Guilty, supra note 9, at 1075. 
guilty criminals going free is disputed, ${ }^{261}$ it appears to be undisputed that the exclusionary rule results in "tens of thousands of contested suppression motions each year."262 These resources could all be redirected towards defendants raising plausible claims of factual innocence. And, it is important to recall, that while the exclusionary rule involves a vast swath of cases in the criminal justice, cases involving the factually innocent - and unable to prove their innocence with existing resources - appear to constitute a tiny fraction. ${ }^{263}$

My point is not that abolishing the exclusionary rule is a perfect solution to the problem of limited criminal justice resources; rather, my more limited (but nonetheless important) point is that a system without the exclusionary rule is better than the existing legal regime, at least when assessed from an innocentric perspective, because it permits significant resources to be redirected towards innocence issues. ${ }^{264}$ Anyone who views these innocentric from an innocentric perspective should endorse such reforms that shift resources toward the innocent.

261 Compare United States v. Leon, 468 U.S. 897, 907 (1984) (arguing that the small percentage researchers deal with masks the large number of felons released from prison based in part on illegal searches and seizures), with id. at 950 (Brennan, J., dissenting) (arguing that only a very small percentage of all felony arrests are declined for prosecution on grounds of potential exclusionary rule problems); see also Robert P. Mosteller, Protecting the Innocent: Part of the Solution for Inadequate Funding for Defenders, Not a Panacea for Targeting Justice, 75 Mo. L. REV. 931, 955-56 (2010) (reporting his own experience that motions to suppress "posed only a minimal drain on defense resources; although his experience came in a system setting motions to suppress for argument on the eve of trial, thereby preventing most such motions from being litigated).

262 McDonald v. City of Chicago, 561 U.S. 742, 785 (2010) (quoting William Stuntz, The Virtues and Vices of the Exclusionary Rule, 20 HARV. J.L. \& PUB. POL'Y 443, 444 (1997)).

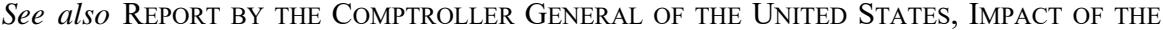
EXClusionary RULe ON Federal CRIMINAL Prosecutions 8 (1979) (10.5\% of all defendants filed a motion to suppress based on search and seizure issues and $0.4 \%$ based on electronic surveillance issues).

263 See generally Cassell, Overstating America's Wrongful Conviction Rate?, supra note 14 (finding low rate of wrongful conviction). Of course a low rate of wrongful conviction is not necessarily identical to a low rate of wrongful charging. But given the parallels between the two - and the relatively small percentage of cases of wrongful conviction-it seems reasonable to conclude that a relatively small percentage of innocent defendants are wrongfully charged.

264 Cf. Worden et al., supra note 253, at 220 ("Were the system to prioritize the needs of the 'truly innocent' over the crowds of the merely 'truly accused,' it is not difficult to image reallocations of defense resources"). 
6. More Research on the Frequency and Causes of Wrongful Convictions

One final proposal on my list of measures to address the problem of wrongful convictions is further research on the extent and causes of the problem. ${ }^{265}$ Indeed, one of my cited authorities for such a proposal was Professor Zalman himself, who had previously written an article in which he had outlined a research agenda for innocence issues. ${ }^{266}$ I explained that "[f]or public policy purposes, we need more information-information about, for example, wrongful convictions through guilty pleas ... and solid information about the incidence of wrongful convictions outside the areas of homicide and rape." ${ }^{267}$ I also cited Professor Samuel Gross' apt observation that "[t]he most important question about false convictions is also the most basic: How frequently are innocent people convicted of crimes?"268

To help answer such questions, I specifically suggested that researchers should draw a random sample of a large number of felony violent crime cases, track them through the system to identify cases in which wrongful conviction was even a possibility, and then press even further to try and get to the bedrock truth in this subset of case. ${ }^{269}$ I noted that such an approach had been followed in other countries. ${ }^{270}$ I concluded that such research "might be very valuable for revealing both the scope of the wrongful conviction problem and particular areas where wrongful convictions are prevalent. This would permit a targeted response to the problem, perhaps more narrowly addressing the risk to the innocent without freeing the guilty."271

This approach would also respond to the problem that most of the current wrongful conviction research involves selecting the dependent variable-i.e., the research begins with a case a wrongful conviction and traces the case's history back to the point at which it veered in the direction of a miscarriage of justice. ${ }^{272}$ This approach makes it difficult to draw firm

265 Cassell, Can We Protect the Innocent?, supra note 11, at 271.

266 See Marvin Zalman \& Julia Carrano, Sustainability of Innocence Reform, 77 ALB. L. REV. 955, 983-93 (2014) (outlining research agenda for innocence issues). Cf. Keith A. Findley, Learning from Our Mistakes: A Criminal Justice Commission to Study Wrongful Convictions, 38 CAL. W. L. REv. 333 (2002). My proposal is slightly different because I propose to conduct research to expand our knowledge about a random sample of wrongful convictions.

267 Cassell, Can We Protect the Innocent?, supra note 11, at 271.

268 Samuel Gross, Convicting the Innocent, 4 ANN. REV. L. Soc. SCI. 173, 176 (2008).

269 Cassell, Can We Protect the Innocent?, supra note 11, at 271.

270 See, e.g., Gisli H. Gudjonsson \& Jon F. Sigurdsson, How Frequently Do False Confessions Occur?: An Empirical Study Among Prison Inmates, 1 PsychOL. CRIM \& L. 21, 25 (1994)

271 Cassell, Can We Protect the Innocent?, supra note 11, at 271.

272 See Worden et al., supra note 253, at 13. 
conclusions about the relative significance of various factors causing wrongful convictions, because some of those factors may be easier to detect than others. For example, if mental disabilities are an especially important cause of wrongful conviction, but persons suffering from such disabilities have great difficulty in bring their plight to the attention of others, existing research will tend to understate the role of these disabilities in wrongful conviction. ${ }^{273}$

In response, while Professor Zalman half-heartedly agrees that " $[t]$ here is nothing objectionable to "more research," ${ }^{274}$ he hastens to add that funders of such a study "would have to evaluate its likely success and the lost opportunity costs of other kinds of research." 275 He then suggests that a different research project - "sentinel event initiation research"- would be one type of project that would be better than the frequency research that I proposed. ${ }^{276}$ Interestingly, in another of his recent articles, Zalman specified as a possible project research into whether "concern with actual innocence weaken [a country's] crime control abilities as some conservative critics claim" 277 - a project that would seem to necessarily involve an inquiry into frequency of various criminal justice events.

One would think that a self-professed "innocentric" scholar would be able to muster a more robust endorsement of a proposal to research the size and scope of the innocent problem. But perhaps Professor Zalman's concern is that the research might indicate that existing research has overstated the magnitude of the problem. For instance, Professor Zalman is quick to cite Professor Risinger's interesting and well-known study, finding a roughly $3.3 \%$ wrongful conviction rate in high profile capital rape-murder cases in the 1980s, before the existence of DNA testing and other, more recentlyadopted protective measures against wrongful convictions. ${ }^{278}$ But the obvious question raised by such studies with such specialized samples is whether, assuming their findings are accurate, they apply more generally to the broader criminal justice system. Indeed, Risinger himself cautioned that his findings were "necessarily subject to... further research,"279 and

273 Cf. Paul G. Cassell, The Guilty and the "Innocent": An Examination of Alleged Cases of Wrongful Conviction from False Confessions, 22 HARV. J. L. \& PUB. POL'y 523, 583-85

(1999) (suggesting mental retardation may be an especially potent cause of false confessions).

274 Zalman, supra note 6, at 1372.

275 Id. at 1373

276 Id.

277 Marvin Zalman, Wrongful Conviction: A Comparative Perspective 33 (May 4, 2016), https://papers.ssrn.com/sol3/papers.cfm?abstract_id=2899482.

278 Id. at 19 (citing D. Michael Risinger, Innocent Convicted, supra note 5). Perhaps in an effort to make the study seem more broadly based than it was, Professor Zalman confusingly describes the study as involving "rape/murder" cases, but in fact it the study involved "capital rape-murders in the 1980s." Risinger, supra, at 768.

279 Risinger, supra note 5, at 799. 
discussed at great length the important question of whether it was possible to "generalize this [error] rate . . to other sets of criminal convictions." 280

Professor Zalman cites to Risinger, who argued (quite correctly in my view) that wrongful convictions were heavily "substructured," by which he meant that certain types of cases are more likely to produce wrongful convictions than others. ${ }^{281}$ But Zalman's conclusion from this point was revealing. Zalman writes that " $[\mathrm{u}]$ ntil the field of wrongful conviction develops techniques parallel to those of geologists who can make costeffective guesses of where to dig, Cassell's proposals could produce a dry well." 282 Of course, a "dry well" finding even in any particular substructure could be very important. It could help researchers prospecting for wrongful convictions one place in the system to focus their efforts elsewhere. For instance, I have previously suggested that an area in which wrongful reform efforts should be directed is cases involving defendants with mental disabilities. ${ }^{283}$ A research finding that, across a broad swatch of cases, wrongful convictions were concentrated among such defendants could be extremely important in channeling concern to this particular area.

Zalman tips his hand when he professes concern about a "dry well" finding. His point about substructuring, of course, applies not just to my proposed research but also to existing research, such as Professor Risinger's. It may be that Professor Risinger has drilled into atypical group of cases (capital rape-murder cases in the 1980s) that are particularly likely to contain wrongful victims. Indeed, Risinger himself seems to admit that this is a possibility. ${ }^{284}$ Research reporting dry wells in other, more typical, parts of the criminal justice system could be important to policy makers trying to assess the size and scope of the problem. Research along the lines proposed should be a high priority for researchers interested in making sound public policy recommendations in this area.

Indeed, I am happy to report that I am not the only one who has seen the need for more research on the frequency of wrongful convictions, including research based on samples from a particular jurisdiction. Professor George Thomas, a distinguished legal scholar who has written frequently on innocence issues, had recently joined me a putting together a set of three articles that engage on this important topic. ${ }^{285}$ Both of us believe that some estimate of the frequency of wrongful convictions is important to the debate on this subject - and both of us have tried to derive estimates of a more

280 Id. at 782; see also id. at 782-88 (exploring this question).

281 Id. at 782-85.

282 Zalman, supra note 6, at 1372-73.

283 See Cassell, supra note 273, at 582-85.

284 See Risinger, supra note 5, at 785-87.

285 See supra note 14 
generally-applicable wrongful conviction rate, including estimates based on jurisdiction-specific samples (from North Carolina and Utah). Professor Thomas and I do not pretend that our research has definitively resolved the subject. But we do hope that it will begin to blaze a path toward greater understanding about the scope of the wrongful conviction problem.

\section{CONCLUSION}

Preventing wrongful conviction of the innocent is a fundamental priority of our criminal justice system. But it is obviously not the system's only goal. Efforts to prevent conviction of the innocent should avoid interfering with other objectives, most prominently the need to convict the guilty and prevent the suffering of future crime victims.

The tradeoffs that inhere in our current criminal justice system can be reconfigured. We might, for example, lower the burden of proof required to send repeat violent felons to prison for new crimes - as Professor Laudan has proposed in this symposium. If Laudan's proposal were implemented as part of a system of extended parole for violent crimes, constitutional objections could be avoided. And the proposal might cost-beneficial, by increasing the certainty of punishment for the guilty while imposing a risk of wrongful conviction only on those who had been duly warned.

But ultimately proposals such as Laudan's require assessing tradeoffs. Some kinds of reforms can largely avoid debate about these tradeoffs - true "win-win" measures that simultaneously reduce the number of innocents wrongfully convicted while increasing (or least not decreasing) the number of violent criminals sent to prison. This article lays out a few such possibilities, including replacing the exclusionary rule with a civil damage remedy, moving confession law away from technical Miranda procedures, confining habeas relief to those with claims of factual innocence, requiring defense attorneys to explore their clients' guilt or innocence, and expanding resources devoted to substantive (rather than procedural) issues in the criminal justice system. If we are truly committed to protecting the innocent, we can and should take such specific steps. We can reduce the risk of wrongfully convicting the innocent without setting free more of the guilty. 